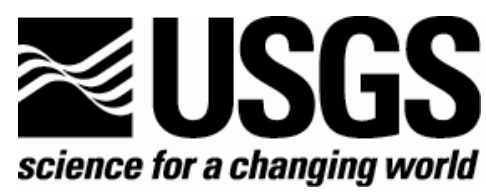

\title{
Known or Suggested Quaternary Tectonic Faulting, Central and Eastern United States-New and Updated Assessments for 2005
}

By Russell L. Wheeler

Open-File Report 2005-1336 


\section{U.S. Department of the Interior \\ Gale A. Norton, Secretary \\ U.S. Geological Survey \\ P. Patrick Leahy, Acting Director}

U.S. Geological Survey, Reston, Virginia 2005

For product and ordering information:

World Wide Web: http://www.usgs.gov/pubprod

Telephone: 1-888-ASK-USGS

For more information on the USGS—-the Federal source for science about the Earth, its natural and living resources, natural hazards, and the environment:

World Wide Web: http://www.usgs.gov

Telephone: 1-888-ASK-USGS

Any use of trade, firm, or product names is for descriptive purposes only and does not imply endorsement by the U.S. Government

This report has not been reviewed for stratigraphic nomenclature

Although this report is in the public domain, permission must be secured from the individual copyright owners to reproduce any copyrighted material contained within this report. 


\section{Contents}

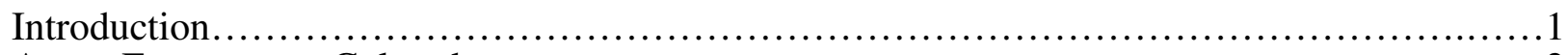

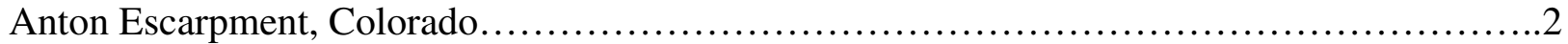

Eastern Arkansas Liquefaction Features, Arkansas........................................ 4

East Border Fault, Connecticut.........................................................

East Coast Fault System, North Carolina, South Carolina, and Virginia........................11

Eastern Tennessee Seismic Zone, Tennessee, Georgia, Alabama, and North Carolina...........13

Fall Lines of Weems, North Carolina, Virginia, and Tennessee.................................17

Giles County Seismic Zone, Virginia and West Virginia..................................... 18

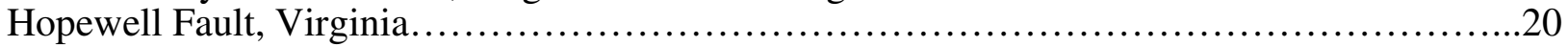

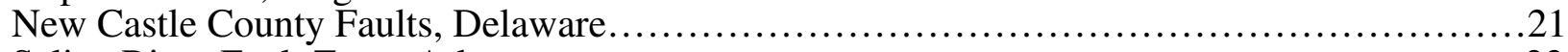

Saline River Fault Zone, Arkansas...................................................22

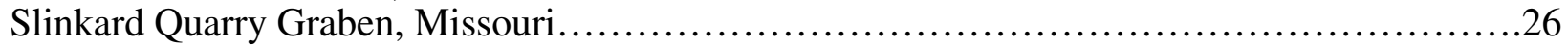

Southeast Arkansas Liquefaction Features, Arkansas..................................... 30

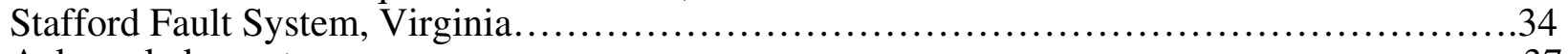

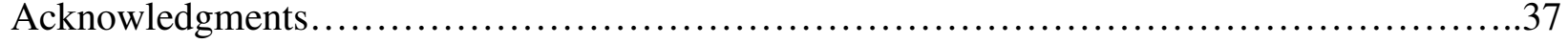




\section{Known or Suggested Quaternary Tectonic Faulting, Central and Eastern United States - New and Updated Assessments for 2005}

By Russell L. Wheeler

\section{Introduction}

The U.S. Geological Survey maintains a Web-searchable, relational database of information on nearly 2,000 features with known or suggested Quaternary tectonic faulting nationwide (http://qfaults.cr.usgs.gov/). The two main uses of the database are (1) for scientific research and (2) to supply data required to calculate estimators of fault activity for use in seismic-hazard computations. The new and updated assessments here are part of the preparation for the 2007-2008 version of the U.S. Geological Survey's national seismic-hazard maps. Eventually, these assessments will be incorporated into the Web-searchable database.

Twelve of the 13 assessments here are new, and the thirteenth incorporates significant new information. The new assessments describe faults, fields of paleoliquefaction features, seismic zones, and geomorphic features for which too little geologic information was available to write an assessment before now. Some of the assessments describe work in progress. They cite mainly abstracts and informal reports to funding agencies. These references are likely to be superseded eventually by formal journal papers.

The format of the assessments is imposed by the structure of the relational database into which the assessments will be incorporated. For example, some assessments repeat the same information in two or more places because the information is pertinent to two or more of the fields in the database. Additionally, the bold-faced titles of some fields and the contents of some fields may seem cryptic. Definitions and explanations are at the Web site mentioned earlier. Finally, the database includes all fields, even if some are blank for lack of information. Accordingly, these assessments include any blank fields to demonstrate the absence of information.

Each fault, liquefaction field, or other feature is assigned to one of four classes. One purpose of the corresponding assessment is to explain the basis of the class assignment. The definitions of the classes start from the assumption that most or all evidence of tectonic faulting occurs seismically as the result of large earthquakes and associated strong ground motion. The assumption is a reasonable approximation in the central and eastern United States (CEUS) for four reasons. First, the most striking geologic signatures of CEUS Quaternary tectonic activity at the scale of individual faults are surface ruptures and liquefaction features, and present paleoseismological methods can only detect surface ruptures and liquefaction produced by moderate to large earthquakes. Second, both main uses of the database deal with seismic hazards, and hazard comes from moderate to large earthquakes. Third, seismic slip is known to occur throughout the CEUS, whereas aseismic creep is harder to demonstrate, and its occurrence is uncertain in the CEUS. Fourth, seismic moment release, and therefore seismic fault slip, is 
dominated by large earthquakes, despite their low frequency compared to the more numerous small earthquakes.

The Web site listed earlier contains a glossary that defines the four classes under the heading "fault class".

Class A: Geologic evidence demonstrates the existence of a Quaternary fault of tectonic origin, whether the fault is exposed by mapping or inferred from liquefaction or other deformational features.

Class B: Geologic evidence demonstrates the existence of Quaternary deformation, but either (1) the fault might not extend deeply enough to be a potential source of significant earthquakes, or (2) the currently available geologic evidence is too strong to confidently assign the feature to Class $\mathrm{C}$ but not strong enough to assign it to Class $\mathrm{A}$.

Class C: Geologic evidence is insufficient to demonstrate (1) the existence of tectonic faulting, or (2) Quaternary slip or deformation associated with the feature.

Class D: Geologic evidence demonstrates that the feature is not a tectonic fault or feature. This category includes features such as joints, landslides, erosional or fluvial scarps, or other landforms resembling fault scarps but of demonstrable nontectonic origin.

Class A and B features are assigned index numbers to ease database searches. These features have the most and best evidence for Quaternary surface deformation. Their assessments follow a more elaborate format with more fields to contain the generally larger amount of information. Class C and D features are not assigned numbers, and their assessments follow a simpler format with fewer fields. In the CEUS, more than one-half of the assessed features fall into Class $\mathrm{C}$ and will require additional work before they can be assigned to one of the other classes.

\section{Anton Escarpment, Colorado}

\section{(Class C)}

\section{Reason for Class C assignment:}

A digital elevation model of part of eastern Colorado reveals a topographic escarpment that trends N. $35^{\circ}$ W. and extends for a distance of at least $135 \mathrm{~km}$ (Matthews, 2004). The northeastfacing escarpment is 20-30 m high. McGovern (1964) mapped the toe of the escarpment as the contact between Pleistocene Peoria Loess to the southwest and the Pliocene Ogallala Formation to the northeast. McGovern (1964) considered the escarpment to be the edge of one of several ridges of loess that were deposited parallel to the direction of then-prevailing winds. Matthews (2004) suggested that the escarpment might be the product of strike-slip faulting because the digital elevation model shows the escarpment to be a linear feature, to contain left-stepping en echelon sections, to be the line at which three ephemeral streams have distinct left-lateral bends of about $1.6 \mathrm{~km}$ each, and to have what appear to be two synthetic shears splaying off the main escarpment.

In 2004, the Colorado Geological Survey trenched the escarpment $11 \mathrm{~km}$ northeast of Anton, Colorado, at $39.8230^{\circ}$ N., $103.1438^{\circ} \mathrm{W}$ (V. Matthews, written commun., June 25, 2004). Colorado Geological Survey staff conducted an informal field review shortly before the trench was filled. At the trench site, the escarpment is $25 \mathrm{~m}$ high and the steeper, upper part is approximately $200 \mathrm{~m}$ wide with a maximum slope angle of $7^{\circ}$ (Noe, 2005). The lower part of the escarpment is an additional $200 \mathrm{~m}$ wide with slope angles of $0^{\circ}-3^{\circ}$ (D.C. Noe, written 
commun., May 4, 2005). From the foot of the escarpment, the valley floor slopes gently northeastward; the 1:24,000-scale Elba SW topographic map shows that ground level about one mile $(1.6 \mathrm{~km})$ northeast of the escarpment toe is roughly $10 \mathrm{~m}$ lower than the toe. The $180-\mathrm{m}-$ long trench extended from the escarpment's crest down the fall line and was 4.5-6.0 m deep (Noe, 2005). Interpretations of ground-penetrating-radar and seismic-refraction data, and of continuous cores from 12 boreholes that were as much as $11.5 \mathrm{~m}$ deep, were used to correlate the stratigraphy exposed in the trench with the shallow subsurface strata beneath the lower part of the escarpment and the adjacent valley to the northeast (Noe, 2005). Four boreholes were aligned along the southeast edge of the trench, and the other eight extended northeastward across the escarpment toe and the valley floor at intervals of 100-600 ft (30-183 m) (D.C. Noe, written commun., May 4, 2005).

Nearly all of the stratigraphic units exposed in the trench dip gently southwestward; those on the northeast-facing escarpment are truncated. The upper part of the exposed section consists of two massive to weakly bedded, calcareous silt (loess) deposits. The upper deposit, which is beneath the crest of the escarpment, is $4.5 \mathrm{~m}$ thick, and the lower deposit is $7.0 \mathrm{~m}$ thick. The two loess deposits are separated by $4.2 \mathrm{~m}$ of uniformly interbedded silt and sand layers that are $1-10 \mathrm{~cm}$ thick; these interbedded deposits may be an eolian(?) sheet sand (Mahan and others, 2005, D.C. Noe, written commun., May 4, 2005). Optically stimulated luminescence dates indicated that the lower and upper loess deposits are comparable in age to the Peoria Loess (34.1-24.2 ka for the lower deposit and 16.4-13.2 ka for the upper deposit) (Mahan and others, 2005). The lower part of the exposed stratigraphic section in the trench consists of a $2.5 \mathrm{~m}$-thick calcareous paleosol, which is, in turn, underlain by $4.5 \mathrm{~m}$ of eolian sand-dune and sheet-sand deposits (Mahan and others, 2005). The calcareous paleosol consists of a clay-rich Bt horizon that has good soil structure and grades downward into a carbonate-rich Bk horizon. Based on the amount of reddening (rubification), the degree of cementation, and the degree of soil development in the paleosol, A.J. Crone and M.N. Machette estimated that deposits in the bottom of the trench might be on the order of 200-300 ka (oral commun., June 30, 2004). Luminescence dates on this oldest exposed stratum are in progress. Several silt- and sand-filled paleostream channels, as much as 5 $\mathrm{m}$ thick, were cut into the older, 7.0-m-thick loess and the underlying calcareous paleosol and eolian sand deposits.

The trench did not expose any faults associated with the topographic escarpment (Noe, 2005), and field correlations of the calcareous paleosol that was exposed in the trench with the distinctive paleosol in the borehole cores showed that the paleosol is not vertically offset across the escarpment. Subsequent, more detailed lithofacies correlations of the cores confirmed this conclusion (Noe, 2005). However, the core from a borehole that was located in the lower part of the escarpment, where slopes are $0^{\circ}-3^{\circ}$, could not be correlated with stratigraphic units in the cores closer to the escarpment; this stratigraphic discontinuity could be interpreted as evidence of faulting (D.C. Noe, oral communs., January 20 and June 6, 2005)(Noe, 2005). Alternatively, this lack of stratigraphic continuity could be the result of non-tectonic processes such as fluvial erosion and deposition.

If the escarpment formed by fluvial processes, then its height indicates that it formed over a time span much longer than the Holocene. Topographic maps show that the drainage network for kilometers around the trenched part of the escarpment consists of small, intermittent streams. The climate is semi-arid. The streams of the area are much too small to have eroded the high escarpment in a few thousand years. Streams large enough to have eroded the escarpment would require a much wetter climate. Additionally, the streams flow northeastward across the escarpment and are incised into it. The streams cross the escarpment in small valleys to which the streams do not appear underfit. Thus, the northeastward flow directions, the incisions, and the fit between the streams and their valleys indicate that the escarpment predates the modern drainage and the semi-arid climate in which the drainage developed.

If the escarpment is a fault scarp, then its height requires that it is the product of multiple large dip-slip faulting events, or numerous oblique-slip faulting events. In either case, the 
southwestern side of the scarp would have moved upward repeatedly. However, the trench and borehole cores confirm that no significant vertical offset exists across the escarpment, so if the escarpment is associated with faulting, then the fault must be located northeast of the trench beneath the valley and possibly between the escarpment and the easternmost borehole. In that case, the fault scarp must have erosionally retreated several hundred meters to the southwest since the last significant movement, which would make the escarpment a fault-line scarp and not a fault scarp. If the escarpment is the product of movement on a fault, then displacement on the fault has not occurred for a long time (hundreds of thousands of years or more), long enough that likely the annual probability of the fault producing significant ground motion is too small to influence seismic-hazard assessments for the region. Regardless, the lack of a demonstrated fault-related origin for the escarpment justifies classifying the Anton escarpment as a Class $\mathrm{C}$ feature.

\section{State(s):}

Colorado

County(s):

Kit Carson

Washington

Physiographic province(s):

Great Plains province

Compiled or modified by and affiliation:

Russell L. Wheeler, U.S. Geological Survey, May 2005

\section{References:}

Mahan, Shannon, Noe, D.C., McCalpin, J.P., and Madole, Rich, 2005, Optically stimulated luminescence dating of loess and sand sheets in the Anton scarp trench, northeast Colorado: Geological Society of America Abstracts with Programs, v. 37, no. 6, p. 14.

Matthews, Vincent, III, 2004, Neogene faulting in Colorado's High Plains: Geological Society of America Abstracts with Programs, v. 36, no. 5, p. 117.

McGovern, E.H., 1964, Geology and ground-water resources of Washington County, Colorado: U.S. Geological Survey Water-Supply Paper 1777, 46 p., 4 pls., scale 1:125,000.

Noe, D.C., 2005, Geological Society of America Abstracts with Programs, v. 37, no. 6, p. 14, Investigations of possible Quaternary faulting on Colorado's High Plains-What is the origin of the Anton scarp?: Geological Society of America Abstracts with Programs, v. 37, no. 6 , p. 14.

\section{Eastern Arkansas Liquefaction Features, Arkansas}

\section{(Class A)}

No. 1034

\section{Synopsis:}

Large sand blows have been found 30-130 km south of the southern end of the New Madrid seismic zone, outside the recognized limit of large liquefaction features attributed to 1811-1812 New Madrid earthquakes. Aerial photographs, Landsat images, soil maps, and aerial reconnaissance in a six-county region identified potential liquefaction features. Field examination, hand augering and ground-penetrating radar surveys aided in siting six trenches at four sites. Three trenches at two sites exposed large young sand blows and feeder sand dikes. Thus, either large New Madrid earthquakes can cause liquefaction farther away than previously thought, or local sources south of the New Madrid seismic zone generate earthquakes that can cause liquefaction. 


\section{Name Comments:}

State(s):

Arkansas

County(s):

Crittenden

Cross

Lee

Phillips

Poinsett

St. Francis

AMS sheet(s):

Memphis

Helena

\section{Physiographic province(s):}

Coastal Plain province

\section{Geologic setting:}

The liquefaction features are located in the south-central part of the Mississippi embayment. In late Precambrian and early Paleozoic time, this area was on or immediately north of the southfacing rifted margin of North America that flanked the Iapetus Ocean (Lillie and others, 1983; Keller and others, 1989; Thomas, 1989; Thomas, 1991; Hildenbrand and Hendricks, 1995). Later, in middle Paleozoic time, thrust sheets of the Ouachita orogen moved north onto the rifted margin. From Late Triassic to Late Jurassic time, a second episode of rifting opened the Gulf of Mexico. Since then, the northern Gulf of Mexico and the Mississippi embayment have been the depocenter for a thick section of primarily terrigenous clastic sediments derived from the North American craton (Salvador, 1991). The New Madrid seismic zone, located 30-130 km northeast of the liquefaction features, is the most seismically active zone in the central and eastern United States. In contrast, in and near the study area, historical earthquakes are few and have small magnitudes (Engdahl, 1988).

\section{Reliability of location:}

Poor.

Compiled at scales of 1:1,425,000 and 1:77,000.

Comments: Al-Shukri and others (2002) showed the locations of three trench sites on a 1:1,425,000-scale map (see "Paleoseismology studies"). Al-Shukri and others (2003) showed the approximate location of a fourth trench site on a 1:77,000-scale topographic map. Individual prehistoric liquefaction features that have been studied are recognized as the type caused by strong ground motion, which was caused by slip on one or more tectonic faults (Obermeier, 1996). However, the causative faults are not yet identified, and too few liquefaction features have been studied so far for their locations and sizes to tightly constrain the sources of the shaking.

\section{Length:}

Comments: Prehistoric liquefaction features are recognized over a large area and have been attributed to earthquakes that occurred on faults that have not yet been identified. Thus, no length can be estimated.

\section{Average strike:}


Comments: Prehistoric liquefaction features are recognized over a large area and have been attributed to earthquakes that occurred on faults that have not yet been identified. Thus, no strike can be estimated.

\section{Sense of movement:}

Comments: Prehistoric liquefaction features are recognized over a large area and have been attributed to earthquakes that occurred on faults that have not yet been identified. Thus, no movement sense can be estimated.

\section{Dip:}

Comments: Prehistoric liquefaction features are recognized over a large area and have been attributed to earthquakes that occurred on faults that have not yet been identified. Thus, no dip or dip direction can be estimated.

\section{Paleoseismology studies:}

Al-Shukri and others (2000a; 2000b; 2005) described large sand blows as far as $100 \mathrm{~km}$ south of the New Madrid seismic zone. Al-Shukri and others (2000a; 2000b; 2003) used aerial photographs, Landsat images, soil maps, and aerial reconnaissance in a six-county region to identify features that could be young faults or liquefaction features. Field examination and hand augering indicated the most promising features for trenching, and ground-penetrating radar (GPR) surveys aided in siting some of the trenches. Six trenches were opened and studied at four sites.

Parkin site (Al-Shukri and others, 2000a; 2005): A 95-m-long trench across a 1.5-km-long tonal and topographic lineament did not expose any evidence of surface ruptures, but heavy rains flooded the trench and precluded detailed logging of the walls. However, exposed sand and clay beds in the trench dip northwestward, leading Al-Shukri and others (2000a) to speculate that the dips might indicate subsurface faulting.

Nancy 1 site (Al-Shukri and others, 2000a; 2002; 2005): A 75-m-long trench crossed a silty sand deposit measuring $107 \mathrm{~m}$ by $55 \mathrm{~m}$ and exposed a sand blow that is approximately $1 \mathrm{~m}$ thick and was fed by at least 45 sand dikes. The sand blow overlies several meters of clay and consists of a loose upper part and a cemented lower part. The two parts of the sand could represent either leaching of the upper part with cementation of the lower part, or two sand blows of different ages.

Nancy 2 site (Al-Shukri and others, 2002; 2005): Two trenches were excavated across two distinct sand deposits. Trench T-1 exposed a sand blow 22-118 cm thick that was fed by five sand dikes that cut the underlying clays. One dike dips steeply but the other four have shallow dips. Trench T-2 exposed a 65- to 130-cm-thick sand blow that was fed by two thin vertical sand dikes and a $20-\mathrm{cm}$-thick dike that dips moderately.

Johnson's Farm site (Al-Shukri and others, 2003): Two perpendicular trenches were excavated across a sand deposit beneath which a GPR survey had detected anomalies interpreted as sand dikes and a tree stump that might yield datable material. The sand deposit is massive and coarsens upward, unlike sand blows that the authors studied elsewhere. The trenches did not reveal any sand dikes, but they did expose structures indicative of soft-sediment deformation near some of the GPR anomalies. Large lobes of sand penetrated downward into the underlying silt, and silt lobes penetrated upward into the sand. The authors considered density inversion to be a more likely cause of the structures than seismic shaking. One GPR anomaly had been correctly interpreted as a stump, which yielded a sample for dating.

Separately from the trenching but in the southernmost county of the same region, Harris and others $(1998 ; 2000)$ and Harris and Sorrells (2003) interpreted shallow, shear-wave seismic- 
reflection profiles as showing evidence of three faults that cut Quaternary deposits. Quaternary dip-slip offset on at least one of the faults is reverse. Fault lengths, strikes, dips, and movement senses are otherwise uncertain. The relation of the faults to nearby liquefaction features also is undetermined.

The large distance between the New Madrid seismic zone and the sand blows implies that either (1) major liquefaction can occur farther than suspected from the seismic zone, or (2) one or more local sources can generate large earthquakes (Al-Shukri and others, 2001; 2005).

\section{Geomorphic expression:}

None. Individual liquefaction features appear as light-colored tonal anomalies on aerial photographs and satellite images and from the air. The lineament at the Parkin site appears as a linear tonal boundary and has 2-3 m of topographic relief (Al-Shukri and others, 2000a; 2005), but no liquefaction was identified at that site.

\section{Age of faulted surficial deposits:}

Pleistocene eolian and fluvial deposits and Holocene meander belts.

\section{Year of historic deformation:}

\section{Most recent prehistoric deformation:}

Latest Quaternary $(<15 \mathrm{ka})$

Comments: Nearly all sand blows recognized to date are within an Illinoian valley train deposit (Al-Shukri and others, 2002). At the Nancy sites (see "Paleoseismological studies"), sand blows overlie clays whose upper parts yielded mid-Holocene, calibrated, radiocarbon dates (Al-Shukri and others, 2005).

\section{Recurrence interval:}

Comments: It is not yet possible to estimate a recurrence interval because the age of the liquefaction features has not been determined, and it is not certain if they are all generated by earthquakes from the same fault or fault system. See "Paleoseismological studies".

\section{Slip-rate category:}

Comments: No causal fault, surface rupture, or dated fault offset is known. There are no data with which to estimate a slip rate. See "Paleoseismological studies".

\section{Compiled or modified by and affiliation:}

Russell L. Wheeler, U.S. Geological Survey, 2005.

\section{References:}

Al-Shukri, H.J., Lemmer, R.E., and Connelly, J.B., 2002, Spatial and temporal characteristics of paleoseismic features in the southern terminus of the New Madrid seismic zone in eastern Arkansas: Technical report to U.S. Geological Survey, Reston, Virginia, under Contract 00HQGR0066, 27 p.

Al-Shukri, H.J., Lemmer, R.E., and Connelly, J.B., 2000a, Spatial and temporal characteristics of paleoseismic features in the southern terminus of the New Madrid seismic zone in eastern Arkansas: Technical report to U.S. Geological Survey, Reston, Virginia, under Contract 00-HQ-GR-0066, 6 p.

Al-Shukri, H.J., Lemmer, R.E., Connelly, J.B., Mahdi, H.H., and Egan, M.A., 2000b, Paleoseismic features in the southern terminus of the New Madrid seismic zone [abs.]: Eos, Transactions of the American Geophysical Union, v. 81, no. 48 (Supplement), p. 857. 
Al-Shukri, H.J., Lemmer, R.E., Mahdi, H.H., and Connelly, J.B., 2001, Spatial and temporal characteristics of paleoseismic features in the southern terminus of the New Madrid seismic zone in eastern Arkansas [abs.]: Seismological Research Letters, v. 72, no. 2, p. 257.

Al-Shukri, H.J., Lemmer, R.E., Mahdi, H.H., and Connelly, J.B., 2005, Spatial and temporal characteristics of paleoseismic features in the southern terminus of the New Madrid seismic zone in eastern Arkansas: Seismological Research Letters, v. 76, no. 4, p. 502-511.

Al-Shukri, H.J., Mahdi, H.H., and Tuttle, Martitia, 2003, Spatial and temporal characteristics of paleoseismic features in the southern terminus of the New Madrid seismic zone in eastern Arkansas: Technical report to U.S. Geological Survey, Reston, Virginia, under Contract 00HQGR0066, 8 p.

Engdahl, E.R., compiler, 1988, Seismicity map of North America: Boulder, Colorado, Geological Society of America Continent-Scale Map 004, 4 sheets, scale 1:5,000,000.

Harris, J.B., Berman, S.A., Beard, W.C., Street, R.L., and Cox, R.T., 1998, Shallow seismic reflection investigations of neotectonic activity in the Lower Mississippi Valley, in Expanded abstracts: Society of Exploration Geophysicists, 68th Annual Meeting, p. 848851.

Harris, J.B., Cox, R.T., Berman, S.A., and Cole, B.W., 2000, Shallow seismic reflection imaging of the Big Creek fault zone in the lower Mississippi Valley: Geological Society of America Abstracts with Programs, v. 32, no. 7, p. 56.

Harris, J.B., and Sorrells, J.L., 2003, Shear-wave seismic reflection imaging of the Big Creek escarpment near Helena Arkansas-Evidence for a tectonic origin: Geological Society of America Abstracts with Programs, v. 35, no. 1, p. 21-22.

Hildenbrand, T.G., and Hendricks, J.D., 1995, Geophysical setting of the Reelfoot rift and relations between rift structures and the New Madrid seismic zone, in Shedlock, K.M., and Johnston, A.C., eds., Investigations of the New Madrid seismic zone: U.S. Geological Survey Professional Paper 1538-E, p. 30.

Keller, G.R., Braile, L.W., McMechan, G.A., Thomas, W.A., Harder, S.H., Chang, W.F., and Jardine, W.G., 1989, Paleozoic continent-ocean transition in the Ouachita Mountains imaged from PASSCAL wide-angle seismic reflection-refraction data: Geology, v. 17, p. 119-122.

Lillie, R.J., Nelson, K.D., De Voogd, Beatrice, Brewer, J.A., Oliver, J.E., Brown, L.D., Kaufman, Sidney, and Viele, G.W., 1983, Crustal structure of Ouachita Mountains, Arkansas-A model based on integration of COCORP reflection profiles and regional geophysical data: American Association of Petroleum Geologists Bulletin, v. 67, p. 907931.

Obermeier, S.F., 1996, Using liquefaction-induced features for paleoseismic analysis, in McCalpin, J.P., ed., Paleoseismology: San Diego, Academic Press, p. 331-396.

Salvador, Amos, 1991, Origin and development of the Gulf of Mexico basin, in Salvador, Amos, ed., The Gulf of Mexico basin: Geological Society of America, The Geology of North America, v. J, p. 389-444.

Thomas, W.A., 1989, The Appalachian-Ouachita orogen beneath the Gulf Coastal Plain between the outcrops in the Appalachian and Ouachita Mountains, in Hatcher, R.D., Thomas, W.A., and Viele, G.W., eds., The Appalachian-Ouachita Orogen in the United States: Geological Society of America, The Geology of North America, v. F-2, p. 537-553.

Thomas, W.A., 1991, The Appalachian-Ouachita rifted margin of southeastern North America: Geological Society of America Bulletin, v. 103, p. 415-431.

\section{East Border Fault, Connecticut}

\section{(Class C)}

\section{Reason for Class C assignment:}

The Hartford basin is the largest onshore Mesozoic-age graben in New England. The basin extends from the north shore of Long Island Sound northward across Connecticut and most of 
Massachusetts. Of its two border faults, the East Border fault has, by far, the larger net vertical slip and, as a result, the Triassic and Jurassic sedimentary and igneous rocks that fill the basin dip eastward (Rodgers, 1985). The East Border fault strikes generally north, dips west, and has a listric subsurface geometry. Southward from central Connecticut the fault curves to strike northnortheast and, farther south, northeast. Where it crosses the shore of Long Island Sound, the fault curves still more to strike east-northeast for a distance of $8-10 \mathrm{~km}$ before returning to a northeast strike under the Sound (Rodgers, 1985). Two kilometers inland from the Sound, the eastnortheast-striking part of the fault passes under the estuary of the Farm River and under the Farm River marsh, through which the river flows (Thompson, 1999).

Thompson (1999) and Thompson and others (2000; 2001) cored the marsh sediments along 20 transects and studied core stratigraphy, chemistry, microfauna, vegetation, and radiocarbon dates. Cores were as long as $4 \mathrm{~m}$. The cored marsh deposits consist of sand, mud, peat, and clay, which were deposited on clayey glacial till of unspecified or unknown thickness.

Thompson (1999) and Thompson and others $(2000 ; 2001)$ reconstructed the past geographic distributions of high marsh (salt marsh; infrequently flooded by salt water) and low marsh (flooded by tides), relative sea-level rise curves, and paleohistories of vertical offsets of dated, originally horizontal peats. The authors interpreted all three reconstructions as indicating that sea level rose in the southeastern part of the Farm River marsh more rapidly than in the northwestern part of the marsh. The stratigraphy of the southeastern part of the marsh is dominated by low marsh and mudflat deposits. In contrast, the stratigraphy of the northwestern part of the marsh is predominantly high marsh deposits. The two parts of the marsh are separated by a stratigraphic transition zone that is $13-30 \mathrm{~m}$ wide where it is crossed by four of the core transects (Thompson, 1999, fig. 3.3).

The difference between the two stratigraphies implies that the southeastern part of the marsh was downthrown with respect to the northwestern marsh. The relative downthrowing occurred in increments that total $1.5 \mathrm{~m}$ since approximately A.D. 0. The authors observed that the downthrowing coincided spatially with the buried trace of the East Border fault. The authors concluded that the fault has been intermittently active since $2 \mathrm{ka}$, being reactivated as a reverse fault in the present-day overall compressional stress field.

Five remaining questions stand between this intriguing conclusion and accepting that the East Boundary fault is an active Quaternary structure. First, no fault surface was reported within the till or the overlying marsh deposits. The boundary between the high marsh deposits, northwest of the inferred fault, and the low marsh deposits, southeast of the inferred fault, spans a distance of several meters to several tens of meters. This width would allow the possibility that a reverse fault displaced pre-Quaternary bedrock beneath the till, but splayed, flattened, or did both upward in the much softer Quaternary till and marsh deposits. Thus, at the cored depths, displacement could be distributed across a wide slope rather than a sharp offset on a fault. Such a geometry could hinder any attempt to demonstrate Quaternary faulting by finding the fault itself.

Second, Thompson (1999, p. 104) refers to "catastrophic erosive events" as a possible alternative explanation for parts of the transition zone. Most of the Farm River marsh is 1-2 km inland from Long Island Sound. However, large hurricanes that struck at high tide might have eroded back the high marsh, leaving elevations more amenable to low marshes or mud flats. Another catastrophic erosive event might have been a tsunami that was caused by a distant submarine earthquake or submarine landslide, such as the deadly tsunami that struck Newfoundland after the 1929 Grand Banks earthquake. The 1929 tsunami runup in Newfoundland reached an elevation of $31 \mathrm{ft}(9.4 \mathrm{~m})$ above sea level at a point $0.6 \mathrm{~km}$ inland (Tuttle and others, 2004).

Third, the analysis lacks evidence that individual increments of the downthrowing occurred suddenly, within the seconds to minutes that an earthquake rupture lasts, or at least more suddenly than could be produced by any alternative, nonfaulting mechanism (Obermeier, 1996; Wheeler, 2002). Thompson (1999, p. 103) noted that the down-dropped high-marsh deposits in 
the southeastern part of the marsh are overlain directly by gray estuarine clay. This sharp change in depositional environment implies a relatively abrupt drowning of the high marsh. However, the duration of the downthrowing might be difficult to quantify for comparison to alternative mechanisms. Thompson (1999) inferred possible dates of faulting offsets from the difference of two relative sea-level curves that he calculated for a series of times 20 years apart. The difference curve drops abruptly at several times, with each drop taking place over 1 to 3 adjacent time intervals. Thus, the duration of each drop can be constrained only to be less than 20-60 years, which allows the possibility that any fault slip occurred slowly, by aseismic creep, instead of rapidly.

Fourth, it is unclear whether the drops in the difference curve are larger than the uncertainty in the curve.

Fifth, the difference curve depends on only two cores. Would the drops in the difference curve be reproduced by several other core pairs that straddle the stratigraphic transition zone or by several transects of cores?

These remaining questions and possible alternative explanations mean that faulting has not been demonstrated in the Quaternary sediments of the Farm River marsh. Accordingly, the East Border fault is classified as Class C.

\section{State(s):}

Connecticut

$\operatorname{County}(\mathbf{s})$ :

New Haven

Physiographic province(s):

New England province

\section{Compiled or modified by and affiliation:}

Russell L. Wheeler, U.S. Geological Survey, May 2005

\section{References:}

Obermeier, S.F., 1996, Using liquefaction-induced features for paleoseismic analysis, in McCalpin, J.P., ed., Paleoseismology: San Diego, Academic Press, p. 331-396.

Rodgers, John, 1985, Bedrock geological map of Connecticut: Connecticut Geological and Natural History Survey and U.S. Geological Survey, 2 sheets, scale 1:125,000.

Thompson, W.G., 1999, Sea level, climate, and land level-Paleoenvironmental records from the Farm River marsh, Branford, Connecticut: Middletown, Connecticut, Wesleyan University, unpublished M.S. thesis, 286 p.

Thompson, W.G., Varekamp, J.C., and Thomas, Ellen, 2001, Fault motions along the eastern border fault, Hartford basin, CT, over the last 2800 years [abs.]: Eos, Transactions of the American Geophysical Union, v. 81, no. 19 (Supplement), p. S311.

Thompson, W.G., Varekamp, J.C., Thomas, Ellen, and de Boer, J.Z., 2000, Neotectonics in coastal Connecticut-Evidence from the Farm River marsh, Branford [abs.]: Eos, Transactions of the American Geophysical Union, v. 80, no. 17 (Supplement), p. S86.

Tuttle, M.P., Ruffman, Alan, Anderson, Thane, and Jeter, Hewitt, 2004, Distinguishing tsunami from storm deposits in eastern North America-The 1929 Grand Banks tsunami versus the 1991 Halloween storm: Seismological Research Letters, v. 75, p. 117-131.

Wheeler, R.L., 2002, Distinguishing seismic from nonseismic soft-sediment structures-Criteria from seismic-hazard analysis, in Ettensohn, F.R., Rast, Nicholas, and Brett, C.E., eds., Ancient seismites: Geological Society of America Special Paper 359, p. 1-11. 


\section{East Coast Fault System, North Carolina, South Carolina, and Virginia}

\section{(Class C)}

Reason for Class C assignment:

The inferred East Coast fault system trends N. $34^{\circ}$ E. from west of Charleston, South Carolina, to southeastern Virginia, a distance of approximately $600 \mathrm{~km}$ (Marple and Talwani, 2000). The East Coast fault system is described as consisting of three right-stepping sections (southern, central, and northern), each $180-220 \mathrm{~km}$ long and trending N. $22^{\circ}-34^{\circ}$ E. Evidence supporting the existence of the fault system is strongest for the southern section and successively sparser northward. Talwani (1982) used relocated microearthquake hypocenters and composite focal mechanisms to interpret the presence of a deeply buried, 25-km-long Woodstock fault that strikes N. $23^{\circ}$ E. at depths of 9-13 km. Marple and Talwani (1993) identified a long, 15-kmwide belt of northeast-aligned subtle topographic highs, northeast-convex river bends, incised river channels, and upward convexities of longitudinal river profiles that they named the zone of river anomalies. Marple and Talwani (1993) suggested recent and continuing tectonic uplift along and northeast of the Woodstock fault. They attributed the uplift to a seismogenic fault zone much longer than the original Woodstock fault, thereby defining the southern section of the East Coast fault system. Marple and Talwani suggested that the buried fault zone might be the source of the M 7.3 (Johnston, 1996) 1886 Charleston earthquake.

Marple and Talwani (2000) added linear aeromagnetic anomalies, faults interpreted on seismicreflection profiles, exposed Pliocene-Pleistocene faults, local breccias, and upwarped strata to further strengthen support for the southern section of the East Coast fault system. In addition, they extended their analysis northeastward and defined the central and northern sections, although each was defined with successively fewer data. Marple and Talwani (2000) noted that most of the river anomalies are in late Pleistocene sediments and concluded that the East Coast fault system was active 130-10 ka, and perhaps remains active. The right-stepping geometry of the fault system, coupled with the east-northeast orientation of greatest horizontal compressive stress (Talwani, 1982; Zoback and Zoback, 1991; Zoback and others, 1991), suggests that rightlateral strike slip on the fault-system sections should produce pull-apart basins between their ends. Talwani and Howard (2001) and Wildermuth and Talwani (2001) described topographic and gravity evidence, respectively, for the existence of a pull-apart basin between the southern and central sections of the fault system. Marple and Talwani (2004) speculated that the fault system once continued still farther northeastward, beyond southeastern Virginia. They further suggested that tectonic events that were part of the late Paleozoic formation of the Appalachian orogen cut off the northeastward continuation of the East Coast fault system and moved it northwestward. If they are correct, then the northeastward continuation would have been uncoupled from the East Coast fault system throughout the Mesozoic rifting and opening of the Atlantic Ocean and would remain uncoupled today. That long history of uncoupling makes it unclear whether the northeastward continuation and the East Coast fault system have similar present-day potential for damaging earthquakes.

The southern end of the southern section of the East Coast fault system is surrounded by sites at which prehistoric paleoliquefaction features document the occurrence of large earthquakes prior to the 1886 Charleston, S.C., earthquake. Other paleoliquefaction features have been discovered scattered throughout the coastal lowlands of South Carolina and southeastern North Carolina (Obermeier, 1996). Talwani and Schaeffer (2001) correlated paleoliquefaction features throughout the region and concluded that seven 1886-sized earthquakes have occurred in the South Carolina Coastal Plain since 6 ka. Talwani (oral commun., 2000, reported by Wheeler and Perkins, 2000) suggested that the most likely sources for all of these earthquakes might be the southern section of the East Coast fault system or the Woodstock fault within it. 
The evidence for recent uplift and possible buried faulting along the southern section of the fault system is good, although there is less evidence supporting Quaternary tectonism along the more northerly sections. Lacking, however, is a demonstration of any sudden uplift anywhere along the fault system. Such evidence alone can distinguish between deformation that occurs seismically, or more slowly by nonseismic processes (McCalpin, 1996; Obermeier, 1996; Wheeler, 2002). The 1886 and prehistoric liquefying earthquakes in coastal South Carolina demonstrate the occurrence of repeated Quaternary tectonic faulting, but the link between these earthquakes and the East Coast fault system or the Woodstock fault remains speculative. Thus, additional tests are needed to confirm the occurrence of Holocene faulting or to confirm that any or all sections of the East Coast fault system potentially can generate strong ground motion. Accordingly, the East Coast fault system is assigned to Class $\mathrm{C}$.

\section{State(s):}

North Carolina

South Carolina

Virginia

\section{$\operatorname{County}(\mathbf{s}):$}

Bladen (N.C.) Cumberland (N.C.) Edgecombe (N.C.) Halifax (N.C.) Harnett (N.C.) Johnston (N.C.) Nash (N.C.) Northampton (N.C.) Robeson (N.C.) Sampson (N.C.) Wilson (N.C.) Berkeley (S.C.) Dillon (S.C.) Dorchester (S.C.) Florence (S.C.) Marlboro (S.C.) Williamsburg (S.C.) Charles City (Va.) Greensville (Va.) New Kent (Va.) Prince George (Va.) Southampton (Va.) Surry (Va.) Sussex (Va.)

\section{Physiographic province(s):}

Coastal Plain province

\section{Compiled or modified by and affiliation:}

Russell L. Wheeler, U.S. Geological Survey, 2005

\section{References:}

Johnston, A.C., 1996, Seismic moment assessment of earthquakes in stable continental regionsIII. New Madrid 1811-1812, Charleston 1886 and Lisbon 1755: Geophysical Journal International, v. 126, p. 314-344.

Marple, R.T., and Talwani, Pradeep, 1993, Evidence of possible tectonic upwarping along the South Carolina coastal plain from an examination of river morphology and elevation data: Geology, v. 21, p. 651-654.

Marple, R.T., and Talwani, Pradeep, 2000, Evidence for a buried fault system in the Coastal Plain of the Carolinas and Virginia-Implications for neotectonics in the southeastern United States: Geological Society of America Bulletin, v. 112, p. 200-220.

Marple, R.T., and Talwani, Pradeep, 2004, Proposed Shenandoah fault and East Coast-Stafford fault system and their implications for eastern U.S. tectonics: Southeastern Geology, v. 43, no. 2, p. 57-80.

McCalpin, J.P., 1996, Paleoseismology: New York, Academic Press, 588 p.

Obermeier, S.F., 1996, Using liquefaction-induced features for paleoseismic analysis, in McCalpin, J.P., ed., Paleoseismology: San Diego, Academic Press, p. 331-396.

Talwani, Pradeep, 1982, Internally consistent pattern of seismicity near Charleston, South Carolina: Geology, v. 10, p. 654-658.

Talwani, Pradeep, and Howard, Scott, 2001, Further evidence of a buried fault under the South Carolina Coastal Plain [abs.]: Seismological Research Letters, v. 72, no. 1, p. 131.

Talwani, Pradeep, and Schaeffer, W.T., 2001, Recurrence rates of large earthquakes in the South Carolina Coastal Plain based on paleoliquefaction data: Journal of Geophysical Research, v. 106, no. B4, p. 6621-6642. 
Wheeler, R.L., 2002, Distinguishing seismic from nonseismic soft-sediment structures-Criteria from seismic-hazard analysis, in Ettensohn, F.R., Rast, Nicholas, and Brett, C.E., eds., Ancient seismites: Geological Society of America Special Paper 359, p. 1-11.

Wheeler, R.L., and Perkins, D.M., 2000, Research, methodology, and applications of probabilistic seismic-hazards mapping of the central and eastern United States-Minutes of a workshop on June 13-14, 2000, at Saint Louis University: U.S. Geological Survey OpenFile Report 00-0390, 18 p.

Wildermuth, Eric, and Talwani, Pradeep, 2001, A detailed gravity survey of a pull-apart basin in northeast South Carolina: Geological Society of America Abstracts with Programs, v. 33, no. 6, p. 240.

Zoback, M.D., and Zoback, M.L., 1991, Tectonic stress field of North America and relative plate motions, in Slemmons, D.B., Engdahl, E.R., Zoback, M.D., and Blackwell, D.D., eds., Neotectonics of North America: Boulder, Colorado, Geological Society of America, Decade Map Volume 1, p. 339-366.

Zoback, M.L., Zoback, M.D., Adams, John, Bell, Sebastian, Suter, Max, Suarez, Gerardo, Jacob, Klaus, Estabrook, Charles, and Magee, Marian, 1991, Stress map of North America: Geological Society of America, 4 sheets, scale 1:5,000,000.

\title{
Eastern Tennessee Seismic Zone, Tennessee, Georgia, Alabama, and North Carolina
}

(Class C)

\begin{abstract}
Reason for Class C assignment:
The northeast-trending Eastern Tennessee seismic zone in the southern Appalachian Mountains is 50-100 km wide and more than $300 \mathrm{~km}$ long (Johnston and others, 1985; Bollinger and others, $1990 ; 1991)$. The Eastern Tennessee seismic zone is the second most active seismic area in the United States east of the Rocky Mountains, after the New Madrid seismic zone (Bollinger and others, 1990). Most of the seismic zone is in eastern Tennessee but the zone also extends short distances into northwesternmost Georgia and northeastern Alabama (Bollinger and others, 1991; Powell and others, 1994; Frankel and others, 1996; Chapman and others, 1997). An area of more diffuse seismicity surrounds the Eastern Tennessee seismic zone proper and extends into western North Carolina, southwestern Virginia, and southeastern Kentucky (Powell and others, 1994), although Powell and others (1994) argued that earthquakes large enough to be felt appear to have decreased since 1977 in western North Carolina.
\end{abstract}

Chapman and others (1997) used a new crustal velocity model (Vlahovic and others, 1998b) to relocate earthquakes in the seismic zone and then computed 26 single-earthquake focal mechanisms. Strikes of nodal planes cluster in the north, northeast, and east directions, and epicenters align along northeast and east trends. Based on these results, Chapman and others concluded that earthquakes in the seismic zone likely occur on faults that strike northeast and east.

Most earthquakes in the Eastern Tennessee seismic zone are in the crystalline basement rocks, which are buried beneath the exposed thrust sheets of Paleozoic rocks in the Appalachian Mountains. Thus, the structures associated with the earthquakes have no clear relation to structures in the thrust sheets or to the exposed geology (Johnston and others, 1985). In this respect, the Eastern Tennessee seismic zone resembles the Giles County seismic zone, which is roughly along the structural grain to the northeast of the Eastern Tennessee seismic zone (Bollinger and Wheeler, 1983, 1988; Johnston and others, 1985) (see Class C feature Giles County seismic zone). Tavernier (2002) analyzed well logs and reprocessed seismic-reflection data from the Swan Creek oil and gas field at the northeastern end of the Eastern Tennessee seismic zone and interpreted a series of northeast-striking normal faults that offset the top of sub- 
thrust basement. He suggested that the faults may have formed during the late Precambrian or Cambrian rifting that led to the Iapetan Ocean, which would be analogous to the faults to which Bollinger and Wheeler (1983) attributed the Giles County seismic zone. Additionally, the seismic-reflection data within the Eastern Tennessee seismic zone indicate the existence of an east-striking fault that cuts, and therefore postdates, the thrust sheets (Tavernier and Williams, 2002). Tavernier and Williams (2002) suggested that the east-striking nodal planes of Chapman and others (1997) might be evidence that the east-striking fault might be seismogenic. Dunn and Chapman (2005) used the double-difference method to relocate earthquakes in the Eastern Tennessee seismic zone and reported that several hypocenters define a tabular zone that strikes east and dips to the north.

Vlahovic and Powell (1999) and Vlahovic and others (1998a; 1998b) inverted P- and S-wave earthquake arrival times to compute a three-dimensional crustal velocity model and improve the location of earthquake hypocenters. They compared the results to maps and inversions of gravity and aeromagnetic data. They observed that the northeast-trending Eastern Tennessee seismic zone is mostly within a low-velocity volume of crust, thereby confirming an earlier result from sparser data and P-wave arrivals alone (Kaufmann and Long, 1996) and consistent with a model involving fluid weakening of the middle crust (Long and Zelt, 1991). The low-velocity crust also has low density and low magnetic susceptibility (Vlahovic and Powell, 1999). The central and most seismogenic part of the seismic zone is about $30 \mathrm{~km}$ wide, extends from 22 to $4 \mathrm{~km}$ in depth, and has approximately vertical sides (Vlahovic and others, 1998b). Vlahovic and Powell (1999) concluded that earthquakes are concentrated in this block of less competent crust. They and Powell (2002) suggested that the less competent block is bordered by more competent blocks and concentrates seismic faulting, thus amplifying an earlier suggestion of Johnston and others (1985).

The Eastern Tennessee seismic zone has had no historical earthquakes of M (magnitude) 5 or larger. However, the historical record is too short to rule out the possibility of large shocks in the zone (M.C. Chapman as reported by Wheeler and Perkins, 2000). The USGS national seismichazard maps used global analogues as a basis for assuming that the seismic zone is capable of having infrequent earthquakes as large as M 7.5 (Wheeler and Frankel, 2000). Large blocks of Paleozoic carbonate rocks that were emplaced in Miocene lake clays, disturbed Quaternary terrace deposits, and large prehistoric landslides have all been suggested as possible evidence of large prehistoric earthquakes (Hatcher and others, 1996; 2000; Whisner and others, 2000; 2001) or neotectonic uplift (Schultz and others, 2000). Cato and others (1992) mentioned the start of preliminary field searches for paleoliquefaction features and other evidence of large prehistoric earthquakes in the Eastern Tennessee seismic zone, but I know of no further report of this work. Whisner and others (2003) mapped bedrock and surficial geology and examined Quaternary terraces in an area covering more than 300 square kilometers in the most seismically active part of the seismic zone. They also examined systematic joints and dewatering features at the Gray site northeast of the seismic zone (Hatcher and others, 2000; Whisner and others, 2003) and folded and faulted saprolite and cobble beds at Tellico Plains at the southern end of the mapped area (Whisner and others, 2000). These studies did not produce clear evidence of earthquakeinduced features.

Thus, despite the observations of small to moderate earthquakes in the Eastern Tennessee seismic zone, which demonstrate subsurface Quaternary tectonic faulting, and despite geophysical interpretations of likely faults at hypocentral depths, no surficial geologic evidence has yet demonstrated the occurrence of large earthquakes within the seismic zone. In particular, no geological evidence has demonstrated the occurrence of prehistoric earthquakes larger than any historical shocks within the seismic zone. Accordingly, the Eastern Tennessee seismic zone is assigned to Class $\mathrm{C}$ for lack of geological evidence of large earthquakes. Note that this evaluation of Quaternary faulting is not a complete guide to seismic hazard of the seismic zone. The most authoritative and reliable assessment of the seismic hazard in the zone is the national seismic hazard maps of the USGS (Open-File Report 97-131, 12 maps, scale 1:7,000,000; http://geohazards.cr.usgs.gov/eq/ and subsequent versions). In the Central and Eastern United 
States (CEUS) east of the Rocky Mountain Front, the distribution of historical earthquakes is a reasonable guide to seismic hazard. In the CEUS, the national seismic hazard maps rely mainly on the distribution of historical seismicity to calculate the hazard. The hazard maps show that, for many parts of the CEUS, even though convincing geologic evidence of large, prehistoric earthquakes is absent, these areas are not free of seismic hazard. The occurrence of significant historical earthquakes in the Eastern Tennessee seismic zone demonstrates that a notable level of seismic hazard exists, and this level of hazard is captured in the national seismic hazard maps.

State(s):

Tennessee

Georgia

Alabama

North Carolina

\section{$\operatorname{County}(\mathbf{s})$ :}

Blount (Tenn.) Bradley (Tenn.) Claiborne (Tenn.) Grainger (Tenn.) Hamblen (Tenn.) Hamilton (Tenn.) Hancock (Tenn.) Hawkins (Tenn.) Jefferson (Tenn.) Knox (Tenn.) Loudon (Tenn.) McMinn (Tenn.) Monroe (Tenn.) Polk (Tenn.) Sevier (Tenn.) Union (Tenn.) Catoosa (Ga.) Chattooga (Ga.) Dade (Ga.) Fannin (Ga.) Floyd (Ga.) Gilmer (Ga.) Gordon (Ga.) Murray (Ga.) Walker (Ga.) Whitfield (Ga.) Cherokee (Ala.) De Kalb (Ala.) Cherokee (N.C.) Graham (N.C.)

\section{Physiographic province(s):}

Valley and Ridge province; Blue Ridge province; Appalachian Plateaus province

\section{Compiled or modified by and affiliation:}

Russell L. Wheeler, U.S. Geological Survey, 2005

\section{References:}

Bollinger, G.A., Johnston, A.C., Talwani, P., Long, L.T., Shedlock, K.M., Sibol, M.S., and Chapman, M.C., 1991, Seismicity of the southeastern United States; 1698 to 1986, in Slemmons, D.B., Engdahl, E.R., Zoback, M.D., and Blackwell, D.D., eds., Neotectonics of North America: Boulder, Colorado, Geological Society of America, Decade Map Volume 1, p. 291-308.

Bollinger, G.A., Sibol, M.S., and Johnston, A.C., 1990, The Eastern Tennessee seismic zoneLargest and most active in the southeastern United States: Geological Society of America Abstracts with Programs, v. 22, no. 7, p. 17.

Bollinger, G.A., and Wheeler, R.L., 1983, The Giles County, Virginia, seismic zone: Science, v. 219, p. 1063-1065.

Bollinger, G.A., and Wheeler, R.L., 1988, The Giles County, Virginia, seismic zoneSeismological results and geologic interpretations: U.S. Geological Survey Professional Paper 1355, 85 p.

Cato, K.D., Gelinas, R.L., and Amick, D.C., 1992, The status of paleoseismic investigations at several inland locales within the southeastern United States: Geological Society of America Abstracts with Programs, v. 24, no. 2, p. 7.

Chapman, M.C., Powell, C.A., Vlahovic, Gordana, and Sibol, M.S., 1997, A statistical analysis of earthquake focal mechanisms and epicenter locations in the Eastern Tennessee seismic zone: Bulletin of the Seismological Society of America, v. 87, no. 1522-1536, p.

Dunn, M., and Chapman, Martin, 2005, Relocation of eastern Tennessee earthquakes using hypoDD [abs.]: Seismological Research Letters, v. 76, no. 1, p. 115-116.

Frankel, A.D., Mueller, C.S., Barnhard, T.P., Perkins, D.M., Leyendecker, E.V., Dickman, N., Hanson, S.L., and Hopper, M.G., 1996, National seismic-hazard maps-Documentation June 1996: U.S. Geological Survey Open-File Report 96-0532, 110 p.

Hatcher, R.D., Jr., Carter, M.W., Clark, G.M., and Mills, H.H., 1996, Large landslides in western Blue Ridge of TN \& NC-Mass-wasting phenomena, products of late Pleistocene climates, or smoking gun for earthquake(s) in east TN?: Geological Society of America Abstracts with Programs, v. 28, no. 7, p. 299. 
Hatcher, R.D., Jr., Whisner, S.C., Munsey, J.W., and Moore, Harry, 2000, Fractures, dewatering, and carbonate blocks in a lake deposit at Gray, northeastern Tennessee-A window into southeastern U.S. Pleistocene(?) tectonics and possible seismicity: Geological Society of America Abstracts with Programs, v. 32, no. 7, p. 28.

Johnston, A.C., Reinbold, D.J., and Brewer, S.I., 1985, Seismotectonics of the southern Appalachians: Bulletin of the Seismological Society of America, v. 75, p. 291-312.

Kaufmann, R.D., and Long, L.T., 1996, Velocity structure and seismicity of southeastern Tennessee: Journal of Geophysical Research, v. 101, no. B4, p. 8531-8542.

Long, L.T., and Zelt, K.-H., 1991, A local weakening of the brittle-ductile transition can explain some intraplate seismic zones: Tectonophysics, v. 186, p. 175-192.

Powell, C.A., 2002, Three dimensional velocity structure in the New Madrid and other SCR seismic zones [abs.]: Eos, Transactions of the American Geophysical Union, v. 83, no. 47 (Supplement), p. 1086.

Powell, C.A., Bollinger, G.A., Chapman, M.C., Sibol, M.S., Johnston, A.C., and Wheeler, R.L., 1994, A seismotectonic model for the 300-kilometer-long Eastern Tennessee seismic zone: Science, v. 264, p. 686-688.

Schultz, Art, Naeser, N.D., and Naeser, C.W., 2000, Large Quaternary debris-flow fans in Great Smoky Mountains National Park-Implications for neotectonic faulting: Geological Society of America Abstracts with Programs, v. 32, no. 2, p. 71-72.

Tavernier, S.A., 2002, Basement faults in the East Tennessee seismic zone-Observations from the area of the Swan Creek field: Knoxville, University of Tennessee, unpublished M.S. thesis, 54 p., 1 plate on compact disk.

Tavernier, S.A., and Williams, R.T., 2002, Basement faults in the East Tennessee seismic zoneObservations from the Swan Creek gas field: Geological Society of America Abstracts with Programs, v. 34, no. 2, p. 31.

Vlahovic, Gordana, and Powell, C.A., 1999, A seismotectonic model for the Eastern Tennessee seismic zone based upon potential field and velocity inversions [abs.]: Seismological Research Letters, v. 70, no. 2, p. 273.

Vlahovic, Gordana, Powell, C.A., Chapman, M.C., and Sibol, Matthew, 1998a, ET1D-New one dimensional P- and S-wave velocity models for the Eastern Tennessee seismic zone: Seismological Research Letters, v. 69, no. 5, p. 441-449.

Vlahovic, Gordana, Powell, C.A., Chapman, M.C., and Sibol, M.S., 1998b, Joint hypocentervelocity inversion for the eastern Tennessee seismic zone: Journal of Geophysical Research, v. 103, no. B3, p. 4879-4896.

Wheeler, R.L., and Frankel, Arthur, 2000, Geology in the 1996 USGS seismic-hazard maps, central and eastern United States: Seismological Research Letters, v. 71, no. 2, p. 273282.

Wheeler, R.L., and Perkins, D.M., 2000, Research, methodology, and applications of probabilistic seismic-hazards mapping of the central and eastern United States-Minutes of a workshop on June 13-14, 2000, at Saint Louis University: U.S. Geological Survey Open-File Report 00-0390, 18 p.

Whisner, S.C., Hatcher, R.D., Jr., and Munsey, J.W., 2001, The possible link between east-west trending faults in the Valley and Ridge province of eastern Tennessee and the Gray fossil site: Geological Society of America Abstracts with Programs, v. 33, no. 2, p. 59.

Whisner, S.C., Hatcher, R.D., Jr., and Munsey, J.W., 2003, Disturbed sediments in the East Tennessee seismic zone-Evidence of large prehistoric earthquakes in East Tennessee?: Southeastern Geology, v. 42, no. 2, p. 67-82.

Whisner, S.C., Hatcher, R.D., Jr., Munsey, J.W., and Mills, H.H., 2000, Disturbed Quaternary terrace deposits in eastern Tennessee-Smoking gun for old earthquakes, hillslope creep, or evidence for megatherium trip and fall?: Geological Society of America Abstracts with Programs, v. 32, no. 2, p. 82. 


\section{Fall Lines of Weems, North Carolina, Virginia, and Tennessee}

\section{(Class C)}

\section{Reason for Class C assignment:}

Weems (1998) examined longitudinal profiles of large drainages that generally flow southeastward or northwestward across the Piedmont and Blue Ridge provinces of North Carolina and Virginia and the southeasternmost belt of Tennessee counties. He identified numerous fall zones, or short stream segments that have anomalously steep gradients and usually one to several rapids or waterfalls. Weems (1998) observed that the fall zones tend to align from stream to stream, and that the alignments follow curvilinear paths that he termed fall lines. He identified seven fall lines that trend generally northeastward, parallel to the regional structural grain, and tend to merge northeastward. Consequently, at the North Carolina/South Carolina border, all seven fall lines span a width of approximately $360 \mathrm{~km}$; whereas, at the Virginia/Maryland border, there are only three fall lines and they span roughly $70 \mathrm{~km}$. The easternmost fall line is the Tidewater fall line, which has been known since colonial times as a source of water power and as a barrier to upstream navigation. The westernmost fall line is in the Great Smoky Mountains of Tennessee and in southwestern Virginia. Figures of Weems (1998) show many of the gradient profiles and identify the fall zones along them.

Weems (1998) considered three hypotheses for the origin of the fall zones and their alignments. He ruled out climatic control and argued against general control by differential hardnesses of rock units, although he noted that some fall zones coincide with hardness changes. He argued that the evidence favors neotectonic control of the fall lines, perhaps by intermittent faulting.

The identification of fall zones is subjective, and the criteria for recognizing them are not stated clearly enough to make the results reproducible. Several profiles show one or more steep sections that were not identified as fall zones, and the reasons of these omissions are unclear. The delineations of fall lines, the argument that differential hardnesses do not explain most fall zones, and the conclusion that a neotectonic origin is the most likely all depend on the choice of fall zones. Because the fall zones are not demonstrably reproducible, tectonic faulting is not yet demonstrated, and accordingly, the fall lines are assigned to Class $\mathrm{C}$.

\section{State(s):}

North Carolina

Virginia

Tennessee

\section{$\operatorname{County}(\mathbf{s})$ :}

Alamance (N.C.) Alexander (N.C.) Alleghany (N.C.) Anson (N.C.) Ashe (N.C.) Avery (N.C.) Buncombe (N.C.) Burke (N.C.) Cabarrus (N.C.) Caldwell (N.C.) Caswell (N.C.) Catawba (N.C.) Chatham (N.C.) Cherokee (N.C.) Clay (N.C.) Cleveland (N.C.) Davidson (N.C.) Davie (N.C.) Durham (N.C.) Edgecombe (N.C.) Forsyth (N.C.) Franklin (N.C.) Gaston (N.C.) Graham (N.C.) Granville (N.C.) Guilford (N.C.) Halifax (N.C.) Harnett (N.C.) Haywood (N.C.) Henderson (N.C.) Iredell (N.C.) Jackson (N.C.) Johnston (N.C.) Lee (N.C.) Lincoln (N.C.) Macon (N.C.) Madison (N.C.) McDowell (N.C.) Mecklenburg (N.C.) Mitchell (N.C.) Montgomery (N.C.) Moore (N.C.) Nash (N.C.) Northampton (N.C.) Orange (N.C.) Person (N.C.) Polk (N.C.) Randolph (N.C.) Richmond (N.C.) Rockingham (N.C.) Rowan (N.C.) Rutherford (N.C.) Sampson (N.C.) Stanly (N.C.) Stokes (N.C.) Surry (N.C.) Swain (N.C.) Transylvania (N.C.) Union (N.C.) Vance (N.C.) Wake (N.C.) Warren (N.C.) Watauga (N.C.) Wayne (N.C.) Wilkes (N.C.) Wilson (N.C.) Yadkin (N.C.) Yancey (N.C.) Blount (Tenn.) Carter (Tenn.) Cocke (Tenn.) Greene (Tenn.) Johnson (Tenn.) Monroe (Tenn.) Polk (Tenn.) Sevier (Tenn.) Unicoi (Tenn.) Washington (Tenn.) Albemarle (Va.) Amelia (Va.) Amherst (Va.) Appomattox (Va.) Arlington (Va.) Bedford (Va.) Brunswick (Va.) Buckingham (Va.) Campbell (Va.) Caroline (Va.) Carroll (Va.) Charlotte (Va.) Chesterfield (Va.) Culpepper (Va.) Cumberland (Va.) 
Dinwiddie (Va.) Fairfax (Va.) Fauquier (Va.) Floyd (Va.) Fluvanna (Va.) Franklin (Va.) Goochland (Va.) Grayson (Va.) Greene (Va.) Greensville (Va.) Halifax (Va.) Hanover (Va.) Henrico (Va.) Henry (Va.) Loudoun (Va.) Louisa (Va.) Lunenburg (Va.) Madison (Va.) Mecklenburg (Va.) Montgomery (Va.) Nelson (Va.) Nottoway (Va.) Orange (Va.) Patrick (Va.) Pittsylvania (Va.) Powhatan (Va.) Prince Edward (Va.) Prince William (Va.) Pulaski (Va.) Rappahannock (Va.) Roanoke (Va.) Smyth (Va.) Spotsylvania (Va.) Stafford (Va.) Sussex (Va.) Washington (Va.) Wythe (Va.)

Physiographic province(s):

Piedmont province; Blue Ridge province

Compiled or modified by and affiliation:

Russell L. Wheeler, U.S. Geological Survey, May 2005

\section{References:}

Weems, R.E., 1998, Newly recognized en echelon fall lines in the Piedmont and Blue Ridge provinces of North Carolina and Virginia, with a discussion of their possible ages and origins: U.S. Geological Survey Open-File Report 98-0374, 52 p.

\section{Giles County Seismic Zone, Virginia and West Virginia}

\section{(Class C)}

\section{Reason for Class C assignment:}

The Giles County seismic zone straddles the northwest-flowing New River in southwestern Virginia and adjacent West Virginia. In 1897, an earthquake of magnitude M 5.9 (Johnston, 1994) occurred within the zone. The earthquake caused Modified Mercalli Intensity VIII in Pearisburg, the seat of Giles County, Virginia, and was felt in twelve States from Indiana to North and South Carolina, and from Alabama to Pennsylvania and Maryland. The 1897 earthquake and several smaller shocks in the vicinity prompted installation of a seismograph network in and around the seismic zone (Bollinger and Wheeler, 1988).

Exposed bedrock in the vicinity of the seismic zone consists of N. $60^{\circ}$ E.-trending, folded and thrust faulted, Cambrian to Devonian rocks of the southern Appalachian Valley and Ridge province (Cardwell and others, 1968; McDowell and Schultz, 1990; Virginia Division of Mineral Resources, 1993). The rocks are part of the Appalachian thrust complex that is 3-6 km thick. The thrust complex and in situ, early Paleozoic strata beneath the thrust complex overlie metamorphic and igneous basement rocks. Within the basement at depths of 7-20 km (Gresko and others, 1985) is the Giles County seismic zone, where hypocenters define a steeply dipping, northeast-striking, tabular zone (Bollinger and Wheeler, 1980; 1983; 1988). The tabular zone strikes N. $44^{\circ}$ E., oblique to the structural grain of the overlying folded and thrust-faulted Paleozoic rocks. The seismic zone appears to be unrelated to the overlying Paleozoic rocks and structures within them (Bollinger and Wheeler, 1988).

The orientation of the tabular zone of hypocenters, together with considerations of the regional tectonic evolution of the eastern United States and adjacent Canada, led Bollinger and Wheeler $(1983 ; 1988)$ to suggest that the seismicity represents contractional reactivation of late Precambrian or Cambrian normal faults, which originated during rifting that produced the Iapetus Ocean. Gresko (1985) and Gresko and others (1985) interpreted seismic-reflection data as showing east-facing normal faults of Cambrian age within the seismic zone but beneath the overlying Appalachian thrust complex.

The seismic zone has no recognized geomorphic expression (see Class $\mathrm{C}$ feature Lindside fault zone and Class D feature Pembroke faults). On a more regional scale, Mills (1986; 1994) and 
Mills and Bartholomew (1986) examined elevations of stream terraces for several tens of kilometers along the New River, within and upstream and downstream from the Giles County seismic zone. Mills (1986) noted that terraces downstream (northwest) of the seismic zone were higher above modern river level than those upstream (southeast) of the zone. He noted that the location and sense of the change in terrace elevation was what would be expected from seismic slip in the seismic zone. However, later Mills and Bartholomew (1986) and Mills (1994) found evidence of a prehistoric course change in the New River, which also could explain the change in terrace elevation. Later, Granger and others (1997) used a novel application of ${ }^{26} \mathrm{Al} /{ }^{10} \mathrm{Be}$ dating to estimate rates of New River downcutting on both sides of the Giles County seismic zone and to suggest faster downcutting downstream (northwest) of the seismic zone, which is consistent with the original observation of Mills (1986).

Mills (1985) conducted the only paleoseismological study of the seismic zone. He found no evidence of seismic shaking, faulting, or surface rupture along the New River in two trenches in the Giles County seismic zone and 18 trenches near the zone.

Thus, despite the occurrence of small to moderate earthquakes, which demonstrate subsurface Quaternary tectonic faulting, and despite geophysical interpretations of likely faults at hypocentral depths, no geologic evidence has yet demonstrated Quaternary surface deformation caused by tectonic faulting within the seismic zone. In particular, no geological evidence has yet demonstrated the occurrence of prehistoric earthquakes larger than any historical shocks within the zone. Accordingly, the Giles County seismic zone is assigned to Class $\mathrm{C}$ herein. Note that this evaluation of Quaternary faulting is not a complete guide to seismic hazard of the Giles County seismic zone. The most authoritative and reliable assessment of the seismic hazard is the national seismic hazard maps of the USGS (Open-File Report 97-131, 12 maps, scale 1:7,000,000; http://geohazards.cr.usgs.gov/eq/, and subsequent versions). In the Central and Eastern United States (CEUS) east of the Rocky Mountain Front, the distribution of historical earthquakes is a reasonable guide to seismic hazard. In the CEUS, the national seismic hazard maps rely mainly on the distribution of historical seismicity to calculate the hazard. The hazard maps show that, for many parts of the CEUS, although convincing geologic evidence of large, prehistoric earthquakes is absent, these areas are not free of seismic hazard. The occurrence of a significant historical earthquake and of continuing smaller earthquakes in the Giles County seismic zone demonstrate that a notable level of seismic hazard exists, and this level of hazard is captured in the national seismic hazard maps.

\author{
State(s): \\ Virginia \\ West Virginia \\ County(s): \\ Giles (Va.) Monroe (W.Va.) \\ Physiographic province(s): \\ Valley and Ridge province
}

\title{
Compiled or modified by and affiliation:
}

Russell L. Wheeler, U.S. Geological Survey, 2005

\section{References:}

Bollinger, G.A., and Wheeler, R.L., 1980, The Giles County, Virginia, seismogenic zone: Geological Society of America Abstracts with Programs, v. 12, no. 7, p. 389.

Bollinger, G.A., and Wheeler, R.L., 1983, The Giles County, Virginia, seismic zone: Science, v. 219 , p. $1063-1065$.

Bollinger, G.A., and Wheeler, R.L., 1988, The Giles County, Virginia, seismic zoneSeismological results and geologic interpretations: U.S. Geological Survey Professional Paper 1355, $85 \mathrm{p}$. 
Cardwell, D.H., Erwin, R.B., and Woodward, H.P., 1968, Geologic map of West Virginia: West Virginia Geological and Economic Survey, 2 sheets, scale 1:250,000.

Granger, D.E., Kirchner, J.W., and Finkel, R.C., 1997, Quaternary downcutting rate of the New River, Virginia, measured from differential decay of cosmogenic ${ }^{26} \mathrm{Al}$ and ${ }^{10} \mathrm{Be}$ in cavedeposited alluvium: Geology, no. 25, p. 107-110.

Gresko, M.J., 1985, Analysis and interpretation of compressional (P-wave) and shear (SH-wave) reflection seismic and geologic data over the Bane dome, Giles County, Virginia: Blacksburg, Virginia Polytechnic Institute and State University, unpublished Ph.D. dissertation, $74 \mathrm{p}$.

Gresko, M.J., Munsey, J.W., and Bollinger, G.A., 1985, Structure of the Giles County, VA seismogenic zone interpreted from seismic reflection data [abs.]: Eos, Transactions of the American Geophysical Union, v. 66, no. 46, p. 974.

Johnston, A.C., 1994, Appendix C-Summary tables, SCR seismicity data base, The earthquakes of stable continental regions-v. 2-Appendices A to E: p. C-1-C-46.

McDowell, R.C., and Schultz, A.P., 1990, Structural and stratigraphic framework of the Giles County area, a part of the Appalachian Basin of Virginia and West Virginia, in Evolution of sedimentary basins-Appalachian Basin: U.S. Geological Survey Bulletin 1839, p. E1E24, 1 pl., scale 1:125,000.

Mills, H.H., 1985, Descriptions of backhoe trenches dug on New River terraces between Radford and Pearisburg, Virginia, June, 1981: U.S. Geological Survey Open-File Report 85-474, 63 p.

Mills, H.H., 1986, Possible differential uplift of New River terraces in southwestern Virginia: Neotectonics, v. 1, p. 75-86.

Mills, H.H., 1994, Distribution of high-level gravels along the course of the New River in southwestern Virginia-Implications for neotectonics: Geological Society of America Abstracts with Programs, v. 26, no. 4, p. 56.

Mills, H.H., and Bartholomew, M.J., 1986, Evolution of the course of the New River in southwest Virginia-Some interpretations based on distribution of high-level gravels in Giles, Montgomery, Pulaski, and Floyd Counties: Geological Society of America Abstracts with Programs, v. 18, no. 3, p. 255.

Virginia Division of Mineral Resources, 1993, Geologic map of Virginia: Virginia Division of Mineral Resources, 1 sheet, scale 1:500,000.

\section{Hopewell Fault, Virginia}

\section{(Class C)}

\section{Reason for Class C assignment:}

Dischinger (1987) defined the fault on the basis of geologic mapping, augur holes, water-well $\operatorname{logs}$, and two trenches across the fault zone. The north-striking fault dips steeply to the east, and reverse movement on the fault has vertically displaced a Paleocene-Cretaceous unconformity 20 $\mathrm{m}$ (Dischinger, 1987). Dischinger (1987) mapped the fault trace for at least $13 \mathrm{~km}$ and named it the Dutch Gap fault zone. Mixon and others (1989) extended the mapped length to $49 \mathrm{~km}$ and renamed the fault after the nearby city of Hopewell (2000 population 22,354). The city is the larger feature, and its name is used here.

Cross section CC' of Mixon and others (1989) shows the fault as cutting an exposed, undivided Quaternary and upper Tertiary unit. The section could be interpreted to suggest Quaternary movement on the fault. However, the accompanying geologic map provides more detail and shows the trace as a dotted line ("concealed") in Quaternary units and a dashed line ("approximately located") in Tertiary units. Where Dischinger (1987) mapped the fault, he reported that the youngest offset unit is the Pliocene Yorktown Formation. Pliocene and Pleistocene terrace deposits generally overlie the Yorktown Formation. Dischinger reported no observed offsets of the terrace deposits. Additionally, W. L. Newell reported that "we never 
observed any offsets on the Pleistocene terraces" (written commun., April 14, 2005).

Accordingly, the Hopewell fault zone is assigned to Class $\mathrm{C}$ because of the lack of demonstrated Quaternary surface deformation.

State(s):

Virginia

$\operatorname{County}(s)$ :

Prince George

Chesterfield

Dinwiddie

Physiographic province(s):

Coastal Plain province

Compiled or modified by and affiliation:

Russell L. Wheeler, U.S. Geological Survey, 2005

References:

Dischinger, J.B., Jr., 1987, Late Mesozoic and Cenozoic stratigraphic and structural framework near Hopewell, Virginia: U.S. Geological Survey Bulletin 1567, 48 p., 2 pls., scale $1: 24,000$.

Mixon, R.B., Berquist, C.R., Jr., Newell, W.L., and Johnson, G.H., 1989, Geologic map and generalized cross sections of the Coastal Plain and adjacent parts of the Piedmont, Virginia: U.S. Geological Survey Miscellaneous Investigations Map I-2033, 2 sheets, scale $1: 250,000$.

\section{New Castle County Faults, Delaware}

\section{(Class C)}

\section{Reason for Class C assignment:}

Spoljaric (1973) used well logs, well samples, and a Vibroseis seismic-reflection survey to infer the existence of a buried, northeast-trending graben southwest of New Castle, northern Delaware. The graben offsets the unconformable contact between Paleozoic metamorphic and igneous rocks and overlying Cretaceous strata of the Coastal Plain province but could not be traced upward into the Coastal Plain units. Farther northeast, Spoljaric (1974) examined satellite imagery, an aeromagnetic map, stream geometries, and foliation in metamorphic rocks to infer possible basement faults that strike north-northeast and north-northwest, $5 \mathrm{~km}$ or less north and west of New Castle. On February 28, 1973, an M 3.8 earthquake occurred 10-15 km northeast of New Castle. Aftershocks and the preferred nodal plane indicated a causal fault striking northeast, parallel to the graben that Spoljaric (1973) had inferred on the opposite side of New Castle (Sbar and others, 1975).

Accordingly, the Delaware Geological Survey conducted a three-stage search for possible young faulting at New Castle. First, a 3-km-long high resolution, seismic reflection profile was run along an abandoned, north-trending railway line in the northern outskirts of New Castle (McLaughlin and others, 2002). Modeling of high-resolution gravity data suggested a graben beneath the middle of the seismic line (Howard, 2000). Interpretations of the reflection data showed Cretaceous and Pleistocene strata offset by numerous faults (McKenna and others, 1999; 2000). Second, two boreholes were sited to penetrate two of the inferred faults and to test the existence of the inferred graben. Both holes were cored to basement and a third hole yielded a gamma-ray log. Findings from all three holes contradicted the interpretation of faults (McLaughlin and others, 2002). Third, five trenches were sited above the up-dip projections of 
other interpreted faults, opened to depths of 5-8 ft (2-3 m), and logged. The trenches provided excellent exposures of Quaternary and Cretaceous formations, but none revealed evidence of faulting (McLaughlin and others, 2002).

McLaughlin and others (2002) noted that these negative findings cannot rule out the presence of deeper parts of the faults that had been interpreted on the seismic profile. However, they concluded that "together these results suggest that there has been minimal or no modern fault activity in this area of New Castle County" (p. 15).

The absence of proven Quaternary faulting requires assignment of the studied part of the New Castle area to Class $\mathrm{C}$. The possibility that young faults exist but do not extend upward to the trenched depths precludes an assignment to Class D.

\section{State(s):}

Delaware

$\operatorname{County}(\mathbf{s})$ :

New Castle

Physiographic province(s):

Coastal Plain

Compiled or modified by and affiliation:

Russell L. Wheeler, U.S. Geological Survey, 2005

\section{References:}

Howard, C.S., 2000, Results of a gravity modeling study along the DGS/USGS seismic line, New Castle, Delaware: Geological Society of America Abstracts with Programs, v. 32, p. 27.

McKenna, T.E., Baxter, S.J., Catchings, R.D., and Goldman, M.R., 2000, High-resolution seismic reflection/refraction imaging of shallow-depth faults in the Atlantic Coastal Plain of Delaware [abs.]: Eos, Transactions of the American Geophysical Union, v. 80, no. 17 (Supplement), p. S223.

McKenna, T.E., Baxter, S.J., Catchings, R.D., Goldman, M.R., and Benson, R.N., 1999, Investigations of shallow-depth faults in the Atlantic Coastal Plain of Delaware, USA [abs.]: Eos, Transactions of the American Geophysical Union, v. 80, no. 46, p. 1050-1051.

McLaughlin, P.C., Baxter, S.J., Ramsey, K.W., McKenna, T.E., and Strohmeier, S.A., 2002, Results of trenching investigations along the New Castle Railroad Survey-1 seismic line, New Castle, Delaware: Delaware Geological Survey Open-File Report 43, 17 p.

Sbar, M.L., Jordan, R.R., Stephens, C.D., Pickett, T.E., Woodruff, K.D., and Sammis, C.G., 1975, The Delaware-New Jersey earthquake of February 28, 1973: Bulletin of the Seismological Society of America, v. 65, p. 85-92.

Spoljaric, Nenad, 1973, Normal faults in basement rocks of the northern Coastal Plain, Delaware: Geological Society of America Bulletin, v. 84, p. 2781-2784.

Spoljaric, Nenad, 1974, Possible new major faults in the Piedmont of northern Delaware and southeastern Pennsylvania and their relationship to recent earthquakes: Southeastern Geology, v. 16, no. 1, p. 31-39, 1 folded plate.

\section{Saline River Fault Zone, Arkansas}

(Class B)

No. 1026

Synopsis: 
Cox and others (2000) described a northwesterly trending alignment of earthquake epicenters that follow the Saline River in central and southeastern Arkansas and is colinear with the northeastern margin of the Monroe uplift. Geomorphic evidence has been used to suggest that the Monroe uplift is the site of late Quaternary deformation (see feature 1025, Monroe uplift in this compilation). The epicenter alignment is cited as evidence that active structures exist in the area of the Saline River lineament. In their search for surficial expression of these active structures, Cox and others (2000) described several small-displacement faults having various strikes that are exposed in several road cuts along a 2.2-km-long section of U.S. Highway 425, south of Monticello, Arkansas. The faults and minor deformation exposed in these road cuts and in nearby trenches that they excavated are small-scale features; the relation of these features to deeper structures and to the diffuse regional seismicity are not well determined and, therefore, these features (collectively named the Saline River fault zone by Cox and others) are classified as Class B features. This classification is further justified because no compelling evidence indicates that the faults visible at the surface are related to a significant seismogenic source that might generate damaging earthquakes.

\title{
Name Comments:
}

Cox and others (Cox and others, 1998; 2000) have conducted field studies of small-displacement faults near Monticello, Arkansas, and related them to a zone of diffuse seismicity along the Saline River lineament. They informally named the faults the "Saline River fault zone" (Cox and others, 2000).

\section{State(s): \\ Arkansas \\ County(s): \\ Ashley \\ Cleveland \\ Dallas \\ Drew \\ Grant \\ Hot Spring}

\author{
AMS sheet(s): \\ El Dorado \\ Greenwood \\ Little Rock
}

\section{Physiographic province(s):}

Coastal Plain province

\section{Geologic setting:}

The faults described in the studies cited here are located in the southern part of the Mississippi embayment in the transition zone of structural styles between the broad downwarp of the embayment to the north and the Gulf of Mexico to the south. In late Precambrian and Early Paleozoic time, this area was located on the rifted margin of North America that flanked the Iapetus Ocean (Thomas, 1989; 1991). Later in Paleozoic time, compressional tectonics in the Ouachita orogen resulted in the transport of large thrust sheets over the margin of the craton. Starting in Late Triassic to Middle Jurassic time, break-up of the supercontinent Pangea resulted in the initial opening of the Gulf of Mexico. The opening continued through the late Jurassic, and from that time to the present, the northern Gulf of Mexico has been the depocenter for a thick section of primarily terrigenous clastic sediments derived from the North American craton (Salvador, 1991). During the Mesozoic and Cenozoic, the northern Gulf of Mexico and southern margin of the North American craton have been characterized by modest to minor deformation, which is expressed mainly in the form of broad downwarps (for example, the Mississippi embayment) and gentle uplifts (for example, the Monroe uplift). The New Madrid seismic zone, 
located $300-400 \mathrm{~km}$ to the northeast, is the most seismically active region in the central and eastern United States. However, in the vicinity of the study area, only 12 known earthquakes (maximum magnitude of about 4.3) have occurred historically (Cox and others, 2000).

\section{Reliability of location:}

Poor.

Compiled at 1:17,000 scale.

Comments: The individual features investigated by Cox and others (2000) are relatively well located on the basis of their descriptions of their field study sites. However, if a Saline River fault zone exists, it is not mapped in any published source. Furthermore, Cox and others (2000) indicate that they are naming the feature in the reports cited here.

\section{Length:}

Comments: There is little evidence that the small folds and faults in the several aligned exposures of Cox and others (2000) are connected by any large, underlying, throughgoing fault. Thus, no length can be estimated.

Average strike: unknown

\section{Sense of movement:}

Normal; Reverse

Comments: In road cuts and adjacent trenches, Cox and others (2000) identified smalldisplacement faults having reverse and normal senses of movement. Fault strikes range from $\mathrm{N}$. $69^{\circ} \mathrm{E}$. for a southerly dipping reverse fault to $\mathrm{N} .55^{\circ} \mathrm{W}$. for a northerly dipping normal fault. Cox and others (2000) inferred dextral strike-slip at both outcrop and crustal scales from various observations.

\section{Dip:}

$34^{\circ}-70^{\circ}, \mathrm{SW}, \mathrm{NW}, \mathrm{SE}, \mathrm{NE}$

Comments: Dips and strikes of small faults in various road cuts and trenches are variable (Cox and others, 2000). Dips range from a low value of $34^{\circ} \mathrm{S}$. on a fault interpreted to be predominantly a lateral slip fault to $70^{\circ}$ for a fault interpreted to be transpressional. Similar to the style of displacement and dip amounts, the dip directions are variable. Reverse faults dip north and south; one normal fault in a road cut dips to the north, whereas two normal faults recognized in a shallow seismic-reflection profile dip to the south.

\section{Paleoseismology studies:}

Six kinds of information define the Saline River fault zone. (1) Small faults are exposed in road cuts and Cox and others (1998; 2000) trenched the faults. (2) Twelve small earthquakes align loosely across a distance of $120 \mathrm{~km}$ along a northwest-trending line (Cox, 1994; Cox and others, 2000). (3) Interpretations of three high-resolution, shear-wave, seismic-reflection profiles show faults (Cox, 1994; Cox and others, 2000; 2004). (4) Southeast-flowing rivers are preferentially on the southwest sides of their valleys, and Pleistocene terraces are preferentially on the northeast sides of the valleys. Cox (1994) interpreted this asymmetry to indicate southwest tilting of crustal blocks, one on each side of the southeast-flowing Saline River. (5) Linear river segments parallel to the fault zone expose small faults, folds, and fractures that deform Quaternary sediments (Cox and others, 1998; 2004). (6) Sand blows are at the southeastern end of the fault zone (see Class A feature No. 1033, Southeast Arkansas liquefaction features) (Cox and others, 2000).

The most detailed information concerning the small faults and folds is reported by Cox and others (2000), who examined deformation at six sites along a 2.2-km-long, north-south transect 
following the route of U.S. Highway 425, south of the city of Monticello, Arkansas. In road cuts along the highway, they found evidence of deformation and excavated trenches short distances from the highway along the projected strikes of features exposed in the road cuts. They mapped the trench exposures in detail and dated a surficial silt deposit using thermoluminescence. In addition, they collected data along a 210-m-long, shallow, shear-wave seismic-reflection profile that traversed the features that they interpret as the principal fault and a secondary fault.

In some road cuts and trenches, they found no faulting, only stratigraphic relations and contacts that suggest possible warping and minor deformation. In other road cuts or trenches, they found faults that had throws on the order of $0.5 \mathrm{~m}$ or more. In general, the scale and extent of deformation seems to be minor to modest and localized. They interpreted a group of three faults at one of the medial sites in their transect to be the principal fault of the Saline River fault zone, and they identified the principal fault trace as striking N. $21^{\circ} \mathrm{W}$., dipping $34^{\circ} \mathrm{S}$. and having a 20to $40-\mathrm{cm}$-wide breccia zone in the Eocene Jackson Formation. They also interpreted moderate to steep dips in the adjacent beds of the Jackson Formation and in the Pliocene-Pleistocene Lafayette gravel as drag folding that is evidence of left transpression.

Interpretation of the seismic-reflection profile revealed two south-dipping normal faults that offset the base of the Jackson Formation a total of about $20 \mathrm{~m}$. The total offset of reflectors appears to decrease in younger units, which suggested to Cox and others (2000) that these faults were active as down-to-the-basin normal faults during Eocene subsidence of the Gulf of Mexico margin. The two faults defined by the seismic-reflection data project upward to the traces of small faults exposed in nearby trenches.

Cox and others (2000) collectively interpreted these various orientations, attitudes, and senses of motion to represent a main fault and secondary faults associated with a northwest-trending primary fault that they inferred is related to the N. $45^{\circ} \mathrm{W}$.-trending Saline River seismicity alignment. They speculated that the Eocene-age normal faults have been reactivated as transpressional faults in the contemporary ENE-WSW compressional stress field. They proposed two deformation events that postdate deposition of the late Wisconsinan Peoria Loess, and noted that even though the cumulative vertical offset from these events is less than $1 \mathrm{~m}$, the amount of lateral slip is unknown. Furthermore, they indicated that the features they studied are oblique to the Saline River fault zone and, therefore, could be only part of a discontinuous, en echelon, strike-slip array. Lastly, they cautioned that the Saline River fault zone may be only one of an unknown number of concealed faults that might pose a seismic hazard to the region.

\section{Geomorphic expression:}

No significant geomorphic expression of faults; the features were only exposed in road cuts along U.S. Highway 425 and in nearby trenches (Cox and others, 2000). All features have small displacements, in most cases less than $0.5 \mathrm{~m}$. In the absence of the road cuts, these features would not have been identified on the basis of any surficial expression.

\section{Age of faulted surficial deposits:}

Range in age from Eocene (Jackson Formation), Pliocene-Pleistocene (Lafayette Gravel) through latest Pleistocene deposits that are thought to be Peoria Loess and Loveland Loess (Cox and others, 2000).

\section{Year of historic deformation:}

\section{Most recent prehistoric deformation: Latest Quaternary $(<15 \mathrm{ka})$}

Comments: Based on stratigraphic evidence, Cox and others (2000) proposed two deformation events younger than deposition of the Peoria Loess, but the evidence of these events is not compelling and the cumulative vertical offset is small $(<1 \mathrm{~m})$. Without strong corroboration or confirmation of these proposed paleoseismic histories by additional studies, these events must be 
considered with caution because of the major implications that they have on seismic-hazard assessments.

\title{
Recurrence interval:
}

Comments: Recurrence intervals are not reported because of lack of age control and information about specific faulting events.

Slip-rate category: unknown

Probably less than $0.2 \mathrm{~mm} / \mathrm{yr}$

Comments: Impossible to determine or estimate realistic slip rates given the limited stratigraphic control, the uncertain amounts of slip, the generally small amount of cumulative deformation, and the difficulty in identifying specific datums whose offset can be measured with some degree of confidence. Based on the lack of geomorphic expression and the small amount of post-Eocene cumulative throw, the slip rates must certainly be very small, probably much less than 0.1 $\mathrm{mm} / \mathrm{yr}$.

\section{Compiled or modified by and affiliation:}

Anthony J. Crone, U.S. Geological Survey, 1998; updated by Russell L. Wheeler, U.S. Geological Survey, 2005.

\section{References:}

Cox, R.T., 1994, Analysis of drainage-basin symmetry as a rapid technique to identify areas of possible Quaternary tilt-block tectonics-An example from the Mississippi embayment: Geological Society of America Bulletin, v. 106, p. 571-581.

Cox, R.T., Harris, J.B., Hill, A.A., Forman, S.L., Gardner, Chris, and Csontos, Ryan, 2004, More evidence for young tectonism along the Saline River fault zone, southern Mississippi embayment [abs.]: Eos, Transactions of the American Geophysical Union, v. 85, no. 47 (Supplement), p. 1752-1753.

Cox, R.T., Van Arsdale, R.B., and Harris, J.B., 1998, Quaternary faulting in the southern Mississippi embayment: Eos, Transactions of the American Geophysical Union, v. 79, no. 17, p. S341.

Cox, R.T., Van Arsdale, R.B., Harris, J.B., Forman, S.L., Beard, William, and Galluzzi, Joseph, 2000, Quaternary faulting in the southern Mississippi embayment and implications for tectonics and seismicity in an intraplate setting: Geological Society of America Bulletin, v. 112, p. 1724-1735.

Salvador, Amos, 1991, Origin and development of the Gulf of Mexico basin, in Salvador, A., ed., The Gulf of Mexico basin: Geological Society of America, The Geology of North America, v. J, p. 389-444.

Thomas, W.A., 1989, The Appalachian-Ouachita orogen beneath the Gulf Coastal Plain between the outcrops in the Appalachian and Ouachita Mountains, in Hatcher, R.D., Thomas, W.A., and Viele, G.W., eds., The Appalachian-Ouachita Orogen in the United States: Geological Society of America, The Geology of North America, v. F-2, p. 537-553.

Thomas, W.A., 1991, The Appalachian-Ouachita rifted margin of southeastern North America: Geological Society of America Bulletin, v. 103, p. 415-431.

\section{Slinkard Quarry Graben, Missouri}

\author{
(Class A)
}

No. 1035

Synopsis: The Slinkard quarry graben strikes northeast, is approximately $500 \mathrm{ft}(152 \mathrm{~m})$ wide, and is filled with syntectonic gravel. Faults that bound the graben or are near it have undergone 
multiple periods of movement including pre-Cenozoic, Paleocene, and at least two periods in the Quaternary, with the youngest being post-Sangamon Geosol and pre-Wisconsinan loess. The northwest margin of the graben juxtaposes Quaternary gravel against late Tertiary Mounds Gravel. The fault on the northwest margin strikes N. $35^{\circ}-40^{\circ}$ E. and dips approximately $74^{\circ} \mathrm{SE}$. Mounds Gravel in the footwall has been rotated to dip $54^{\circ}-85^{\circ} \mathrm{SE}$., with strike parallel to the fault.

Name Comments: The Slinkard quarry is within the city limits of Cape Girardeau, Missouri. A Quaternary graben is partly exposed in the quarry.

\author{
State(s): \\ Missouri \\ County(s): \\ Cape Girardeau
}

\title{
AMS sheet(s):
}

Paducah

\section{Physiographic province(s): \\ Ozark Plateaus}

Comments: The Slinkard quarry graben is within the city limits of Cape Girardeau, Missouri, and geographically the city is within the Ozark Plateaus physiographic province. However, trenching at the Slinkard quarry shows the graben to be within an erosional outlier of the sediments of the Coastal Plain province.

Geologic setting: The graben that is exposed in the Slinkard quarry is at the north edge of the Mississippi embayment and north of the Reelfoot rift, which contains the New Madrid seismic zone. Exposed bedrock near the graben is mainly of Middle Ordovician age, with small areas of Silurian and Devonian rocks (Anderson and others, 1979). The quarry is within the Cape Girardeau fault system, a broad belt of generally northwest-striking strike-slip faults that branch, anastomose, and dip steeply (Harrison and Schultz, 2002). Many faults in the system underwent repeated strike slip of various orientations and senses in stress fields of different orientations. Harrison and Schultz (2002) describe examples that illustrate the complex history of stress orientations and fault slips in the fault system.

\section{Reliability of location: Good}

Comments: UTM coordinates (NAD 83 projection) on the northwest boundary fault of the Slinkard quarry graben are $270471 \mathrm{E}, 4134994 \mathrm{~N} \pm 19 \mathrm{ft}$; latitude $37^{\circ} 20.0^{\prime} \mathrm{N}$., longitude $89^{\circ} 35.7^{\prime}$ W.

\section{Length:}

Comments: The total length of the Slinkard quarry graben is unknown, but the northwestern margin fault is at least $180 \mathrm{~m}$ long.

\section{Average strike:}

Comments: The azimuth of the northwest border fault of the Slinkard quarry graben is $+35^{\circ}$ to $+40^{\circ}$.

Sense of movement: normal dextral 
Comments: The Slinkard quarry graben is interpreted to be a pull-apart graben in a dextral strikeslip system.

\section{Dip: $74^{\circ} \mathrm{SE}$}

Comments: The northwestern boundary fault of the Slinkard quarry graben dips $74^{\circ} \mathrm{SE}$.

Paleoseismology studies: Figure 15 of Harrison and Schultz (2002) shows the locations of five trenches across and near the northwest border fault of the Slinkard quarry graben. The trenches were sited and studied to determine stratal ages and structural relations but not to identify individual faulting events. The northeast-striking graben is filled with unsorted, nonbedded gravel and sand of probable Illinoian age. The top of the graben filling has a thick weathering horizon that is well developed. Harrison and Schultz (2002) interpreted the weathering horizon as the Sangamon Geosol. However, the weathering horizon is found only on the graben filling. These observations imply (1) significant Quaternary normal faulting before or during Sangamon time, followed by (2) development of the geosol both on the graben filling and on materials outside the graben, (3) additional post-Sangamon faulting, and (4) erosion to remove the geosol from the relatively upthrown blocks outside the graben. Thus, Harrison and Schultz (2002) inferred that the graben-bounding fault underwent at least two episodes of Quaternary faulting.

The northwest border fault of the graben was exposed, and Harrison and Schultz (2002) described it in detail. It is at least $180 \mathrm{~m}$ long. The northwest margin of the graben juxtaposes Quaternary gravel against late Tertiary Mounds Gravel. The fault on the northwest margin strikes N. $35^{\circ}-40^{\circ}$ E. and dips approximately $74^{\circ} \mathrm{SE}$. Mounds Gravel in the footwall has been rotated to $\operatorname{dip} 54^{\circ}-85^{\circ} \mathrm{SE}$., with strike parallel to the fault. Numerous subsidiary, clay-filled fractures parallel the border fault and are as much as several inches (centimeters) wide. Right-lateral horizontal offset of a few inches (centimeters) of several piercing points was observed on these fractures. Additional clay-filled fractures strike east and offset the graben filling in a normal sense. From these observations, Harrison and Schultz (2002) concluded that the Quaternary normal faulting at the graben occurred under east-northeast maximum horizontal compressive stress, which would be parallel to the present-day stress orientation (Zoback and others, 1991; Zoback, 1992). Harrison and Schultz (2002) summarized a written communication that described the now-covered southeast border fault of the Slinkard quarry graben. Ira Satterfield (Missouri Division of Geology and Land Survey), in an oral communication to Harrison in or shortly before 2000, has reported seeing faulted Peoria Loess on the southeastern margin of the graben during the early 1970s; this site is no longer available for inspection. Faulted loess would be consistent with the post-Sangamon movement on the northwest border fault.

Topographic contours in figure 15 of Harrison and Schultz (2002) indicate more than $3 \mathrm{~m}$ of normal offset across the northwest border fault of the Slinkard quarry graben. An accompanying cross section suggests several times that much Quaternary normal offset.

In a road cut approximately $1 \mathrm{~km}$ southeast of the quarry, Mounds Gravel and overlying Quaternary gravel strike N. 50 $\mathrm{W}$., dip $55^{\circ} \mathrm{NE}$., and are overlain unconformably by Roxana Silt(?) and Peoria Loess. No fault is exposed there, but the similar strata and structural relations indicate that likely the deformation was contemporaneous with faulting at the Slinkard quarry graben (Harrison and Schultz, 2002). The dipping beds might overlie a northwest-striking, mainly strike-slip fault that borders one of the rhomb grabens mapped in the area (Harrison and Schultz, 2002, figure 13). The block northeast of the inferred fault would be inside the rhomb graben and would have dropped down.

Geomorphic expression: none (area has been quarried).

Age of faulted surficial deposits: Late Tertiary Mounds Gravel, Illinoian? deposits that are roughly equivalent to the Metropolis Fm. of Illinois usage, and Sangamon Geosol. 
Comments: The northwest border fault of the Slinkard quarry graben slipped in pre-Cenozoic and Paleocene time and at least twice during the Quaternary Period. The youngest movement postdated the offset Sangamon Geosol and predated the Wisconsinan Peoria Loess. Recent investigation found no evidence of Holocene activity on the northwestern margin of the graben. However, Ira Satterfield (Missouri Division of Geology and Land Survey), in an oral communication in or shortly before 2000, has reported seeing faulted Peoria Loess on the southeastern margin of the graben during the early 1970s; this site is no longer available for inspection.

\section{Year of historic deformation:}

\section{Most recent prehistoric deformation: late Quaternary (<130 ka)}

Comments: Sangamon Geosol is faulted; Peoria Loess is not faulted along the northwestern margin of graben. Recent investigation found no evidence of Holocene activity on the northwestern margin of the graben. However, Ira Satterfield (Missouri Division of Geology and Land Survey), in an oral communication in or shortly before 2000, has reported seeing faulted Peoria Loess on the southeastern margin of the graben during the early 1970s; this site is no longer available for inspection.

\section{Recurrence interval: not determined}

Comments: The geologic records of individual earthquakes have not been identified, so no recurrence interval can be calculated.

Slip-rate category: less than $0.2 \mathrm{~mm} / \mathrm{yr}$

Comments: Unfaulted Peoria Loess overlies the northwest border fault in the Slinkard quarry graben. The loess is late Pleistocene, or $10 \mathrm{ka}$ at the youngest. Assuming this youngest age, and if the largest normal offset that could go undetected at the fault were $1 \mathrm{~cm}$ to $1 \mathrm{~m}$, then the fastest fault-parallel normal-slip rate would be much less than $0.2 \mathrm{~mm} / \mathrm{yr}$. Vertical slip rates would be still smaller, by a factor of 0.96 (the sine of the $74^{\circ}$ dip of the fault).

\section{Compiled or modified by and affiliation:}

Richard W. Harrison and Russell L. Wheeler, U.S. Geological Survey, 2005.

\section{References:}

Anderson, K.H., Dean, T.J., Hebrank, A.W., Miller, D.E., Robertson, C.E., Rueff, Ardel, Satterfield, I.R., Stout, L.N., Thacker, J.L., Thompson, T.L., Wells, J.S., Whitfield, J.W., Kisvarsanyi, E.B., Emerson, John, Pratt, W.P., and Thomson, K.C., 1979, Geologic map of Missouri: Missouri Geological Survey, 1 sheet, scale 1:500,000.

Harrison, R.W., and Schultz, Art, 2002, Tectonic framework of the southwestern margin of the Illinois basin and its influence on neotectonism and seismicity: Seismological Research Letters, v. 75, no. 5, p. 698-731.

Zoback, M.L., 1992, First- and second-order patterns of stress in the lithosphere-The World Stress Map Project: Journal of Geophysical Research, v. 97, no. B8, p. 11,703-11,728.

Zoback, M.L., Zoback, M.D., Adams, John, Bell, Sebastian, Suter, Max, Suarez, Gerardo, Jacob, Klaus, Estabrook, Charles., and Magee, Marian, 1991, Stress map of North America: Geological Society of America, 4 sheets, scale 1:5,000,000. 


\title{
Southeast Arkansas Liquefaction Features, Arkansas
}

\section{(Class A)}

No. 1033

\section{Synopsis: \\ Aerial photographs show thousands of circular and elliptical, light-colored tonal anomalies scattered throughout a multicounty region $150-300 \mathrm{~km}$ southwest of the New Madrid seismic zone. Field examination showed that the anomalies are sand blows caused by strong seismic shaking. Clusters of abundant sand blows define three liquefaction fields. Six trenches in two of the fields indicate that both fields underwent a major liquefaction event 5500-4600 yr ago and one field had a second major event roughly $700 \mathrm{yr}$ ago. There have been several smaller liquefaction events. The sand blows represent either (1) distant effects of very large New Madrid earthquakes, or (2) a newly recognized source of large earthquakes. The first possibility would imply that New Madrid earthquakes can cause strong shaking at much greater distances than suspected. Field observations indicate that the second possibility may be the more likely explanation.}

\section{Name Comments:}

\author{
State(s): \\ Arkansas \\ County(s): \\ Ashley \\ Desha \\ Jefferson \\ Lincoln
}

\author{
AMS sheet(s): \\ Greenwood \\ Helena \\ Little Rock
}

\section{Physiographic province(s): \\ Coastal Plain province}

\section{Geologic setting:}

The liquefaction features are located in the southern part of the Mississippi embayment. In late Precambrian and early Paleozoic time, this area was on the south-facing rifted margin of North America that flanked the Iapetus Ocean on its north (present-day orientation) (Thomas, 1989; 1991). Later, in middle Paleozoic time, thrust sheets of the Ouachita orogen moved north onto the rifted margin. From Late Triassic to Late Jurassic time, a second episode of rifting opened the Gulf of Mexico. Since then, the northern Gulf of Mexico and the Mississippi embayment have been the depocenter for a thick section of primarily terrigenous clastic sediments derived from the North American craton (Salvador, 1991). The New Madrid seismic zone, located 150$300 \mathrm{~km}$ to the northeast of the liquefaction features, is the most seismically active zone in the central and eastern United States. In contrast, in and near the study area, historical earthquakes are few, and they have small magnitudes (Engdahl, 1988; Cox and others, 2004b). A southeasttrending zone along the Saline River contains small exposed faults and folds, a loose northwestsoutheast alignment of 12 small earthquakes, three high-resolution, shear-wave, seismicreflection profiles that have been interpreted as showing subsurface faults, asymmetries in river morphology, and linear river segments with folded, faulted, and fractured sediments along them (Cox and others, 2000b). Cox and others (2000b) interpreted this alignment to indicate the 
existence of the Saline River fault zone (see Class B feature No. 1026). The Southeast Arkansas liquefaction features are clustered at and near the southeastern end of the fault zone.

\section{Reliability of location:}

Poor.

Compiled at scales from 1:17,000 to 1:40,000, and 1:1,250,000.

Comments: Individual liquefaction features and the sites of trenches in the features are well located on annotated aerial photographs of Cox and Larsen (2004) and Cox and others (2004b) at scales from 1:17,000 to 1:40,000. In addition, aerial photographs identify 640-acre sections containing circular and elliptical tonal anomalies that are characteristic of liquefaction features. The sections and the liquefaction fields in which the sections cluster are shown at 1:1,250,000scale (Cox and Larsen, 2004). The individual prehistoric liquefaction features that have been studied are recognized as the type that is caused by strong ground motion, which was itself caused by slip on one or more preexisting, deep-seated, tectonic faults (Obermeier, 1996). However, the causative faults are not yet identified and too few liquefaction features have been studied so far for their locations and sizes to tightly constrain the sources of the shaking.

\section{Length: unknown}

Comments: Individual Quaternary faults have not been identified. Instead, prehistoric liquefaction features are recognized over a large area and attributed to earthquakes that occurred on unidentified faults. Thus, no length can be estimated.

\section{Average strike: unknown}

Comments: Individual Quaternary faults have not been identified. Instead, prehistoric liquefaction features are recognized over a large area and attributed to earthquakes that occurred on unidentified faults. Thus, no strike can be estimated.

\section{Sense of movement: unknown}

Comments: Individual Quaternary faults have not been identified. Instead, prehistoric liquefaction features are recognized over a large area and attributed to earthquakes that occurred on unidentified faults. Thus, no movement sense can be estimated.

\section{Dip:}

Comments: Individual Quaternary faults have not been identified. Instead, prehistoric liquefaction features are recognized over a large area and attributed to earthquakes that occurred on unidentified faults. Thus, no dip or dip direction can be estimated.

\section{Paleoseismology studies:}

Cox and others (2000a) first described a field of liquefaction features within the southern Mississippi embayment, in a region of sparse historical seismicity approximately $150-300 \mathrm{~km}$ southwest of the New Madrid seismic zone. Aerial photographs show that thousands of circular and elliptical, light-colored tonal anomalies are scattered throughout the region (Cox and Larsen, 2004; Cox and others, 2004b). Field examinations showed that the anomalies are sand blows with characteristics that Obermeier (1996) concluded originate in strong seismic shaking. Clusters of abundant sand blows define three liquefaction fields. Within each field, Giddings-rig push-cores delineated shallow stratigraphy. Ground conductivity surveys allowed mapping of shallow sand bodies and aided the later siting of trenches. The Ashley County liquefaction field is the southernmost of the three fields. Within the Ashley field, two trenches were studied at the Montrose site, a third at the Portland site and a fourth at the Morgan site. Approximately $10 \mathrm{~km}$ north of the edge of the Ashley field is the border of the Desha County liquefaction field, which 
was studied with one trench at the Golden site and a second trench at the Kelso site. Thirty km northwest of the Desha field is the Jefferson/Lincoln County liquefaction field, which had not yet been trenched when Cox and Larsen (2004) wrote their report.

Stratigraphic, structural, and other relations in the two trenches at the Montrose site in the Ashley field indicate five liquefaction events (Cox and others, 2004b). (1) The oldest sand blow deposit is thin and older than 5320-5055 cal. yr BP. (2) A second thin sand blow deposit is younger than $6.4 \pm 0.5 \mathrm{ka}$. (3) A thick sand blow deposit buries the second blow and is younger than $5.8 \pm 0.4 \mathrm{ka}$ but older than 1550-1300 cal. yr BP. (4) A set of sand dikes is younger than the third sand blow deposit but has only the same age constraints. (5) A vent crater filled with organic-rich sediments and the sand dikes that feed the crater are younger than 740-560 cal. yr BP.

The trench at the Portland site in the Ashley field revealed the records of two or three liquefaction events (Cox and others, 2004b). (1) A probable venting episode occurred between 5040-4840 cal. yr BP and 990-910 cal. yr BP (2) A thick sand blow formed between 990-910 cal. yr BP and 500-150 cal. yr BP. (3) A sand dike cuts the thick blow but lacks other age constraints. The dike may represent "late-stage venting associated with deposition of the principal blow" of event (2) (Cox and others, 2004b, p. 1132).

The trench at the Morgan site in the Ashley field exposed an old, thin sand blow deposit and a young, thick sand blow deposit (Cox and Larsen, 2004). Radiocarbon dates are in progress (Cox and others, 2004c). Luminescence dates restrict the deposition of the older sand blow to within 7690-5725 yrs BP and the younger sand blow to after 6845 yrs BP (Cox and others, 2004a). Additionally, a surface soil developed on exposed parts of the thick, younger sand blow may have formed over "a few hundred years" (Cox and Larsen, 2004, p. 14). Thus, Cox and Larsen (2004) consider both sand blows to predate the 1811-12 New Madrid earthquake sequence.

The trench at the Kelso site in the Desha field demonstrated three or four liquefaction events (Cox and others, 2004b). (1) A thick sand blow deposit is younger than 5.7 $\pm 0.6 \mathrm{ka}$. (2) A crater filled with organic-rich sediment and its feeder vent formed after the thick sand blow was deposited and after 2310-2010 cal. yr BP. (3) A second crater and vent also formed after the thick blow and after 1310-960 cal. yr BP. (4) A third crater and vent postdated the thick blow and formed after 1030-740 cal. yr BP. Venting episodes (3) and (4) have overlapping age ranges and may represent a single episode.

The trench at the Golden site in the Desha field exposed evidence of at least one liquefaction event (Cox and Larsen, 2004). A thick sand blow is older than 510-290 cal. yr BP. Small sand lenses beneath the thick blow may represent an older liquefaction event. Additional dating results are in progress (Cox and others, 2004c). A surface soil developed on exposed parts of the thick sand blow may have formed over "a few hundred years" (Cox and Larsen, 2004, p. 14). Thus, the sand blow predates the 1811-12 New Madrid earthquake sequence.

Field reconnaissance of the Phenix site in the Jefferson/Lincoln County liquefaction field suggested that vented sands there were erupted between approximately 4500-3000 yr BP. and roughly 2200 yr BP (Cox and Larsen, 2004).

Cox and others (2004b) concluded that the Ashley and Desha fields underwent a major liquefaction event 5500-4600 yr ago, the Ashley field had a second major event roughly $700 \mathrm{yr}$ ago, and there have been several smaller events. The first major liquefaction event predates the liquefaction chronology that has been developed thus far in the New Madrid seismic zone and cannot be compared to it, but the second major event is inconsistent with the New Madrid chronology as summarized by Tuttle and others (2002). Cox and others (2004b) concluded that either (1) at least some of the southeast Arkansas liquefaction represents distant effects of very large New Madrid earthquakes, which would imply that the area shaken strongly by New Madrid earthquakes is much larger than suspected, or (2) the Ashley and Desha fields represent one or more newly recognized sources of large earthquakes. 
Cox and Gardner (2003) and Cox and Larsen (2004) observed that the liquefaction fields, with their abundant sand blows, are separated by continuous Holocene liquefiable deposits having few or no sand blows. From this observation they and Cox and others (2004b) suggested that the fields may be more likely to represent one or more newly recognized, independent sources of local earthquakes of M 5.5-6.5. However, note that the estimation of magnitude from the locations of associated liquefaction features depends on distance to the farthest liquefaction. Figure 2 of Cox and Larsen (2004) shows that the trenches in the Ashley and Desha liquefaction fields are all near the edges of the fields. Nonetheless, the sand blows exposed in the trenches are many meters wide, and some of them are decimeters to a meter thick. Such large blows may be unlikely to represent the farthest liquefaction. If the farthest liquefaction features are still more distant than these large blows, then perhaps the Holocene earthquakes of southeastern Arkansas were larger than M 5.5-6.0.

\section{Geomorphic expression:}

Individual liquefaction features appear as circular or elliptical, light tonal patches on aerial photographs. On the photographs, linear sand blows and strings of sand blows are difficult to distinguish from fluvial deposits. Individual sand blows are scattered widely. Studies of these features have concentrated on three liquefaction fields in which many sand blows are present (Cox and others, 2004b).

\section{Age of faulted surficial deposits:}

Vented sand lies on Holocene meander belt and backswamp deposits and Early Wisconsinan terraces of the Arkansas River (Cox and Larsen, 2004). Interpretations of two S-wave seismicreflection profiles near liquefaction features show several faults that cut through the Quaternary section. However, it is not known whether seismic slip on the faults produced the liquefaction features.

\section{Year of historic deformation:}

\section{Most recent prehistoric deformation:}

Latest Quaternary $(<15 \mathrm{ka})$

Comments: Details of timing of the liquefaction events remain uncertain because they depend on how the Holocene liquefaction features are correlated (Cox and Larsen, 2004). Resolution of the uncertainty requires more study and dates. See "Paleoseismological studies" and "Age of faulted surficial deposits".

\section{Recurrence interval:}

Comments: Estimation of recurrence intervals would be premature because they would depend on how liquefaction features are correlated. See "Paleoseismological studies".

\section{Slip-rate category: unknown}

Comments: No causal fault, surface rupture, or dated fault offset is known to be associated with these liquefaction features. There are no data with which to estimate a slip rate. See

"Paleoseismological studies".

\section{Compiled or modified by and affiliation:}

Russell L. Wheeler, U.S. Geological Survey, 2005.

\section{References:}

Cox, R.T., Doughty, P.T., McHugh, J., and Galluzzi, J., 2000a, Locally strong ground shaking suggested by a possible liquefaction field above the Saline River fault zone in the southern 
Mississippi embayment: Geological Society of America Abstracts with Programs, v. 32, no. 2 , p. 13.

Cox, R.T., and Gardner, Chris, 2003, A possible sand blow field in the central Arkansas River valley of the southwestern Mississippi embayment: Geological Society of America

Abstracts with Programs, v. 35, no. 6, p. 582.

Cox, R.T., Harris, J.B., Hill, A.A., Forman, S.L., Gardner, Chris, and Csontos, Ryan, 2004a, More evidence for young tectonism along the Saline River fault zone, southern Mississippi embayment [abs.]: Eos, Transactions of the American Geophysical Union, v. 85, no. 47 (Supplement), p. 1752-1753.

Cox, R.T., and Larsen, D., 2004, Investigation of seismically-induced liquefaction in the southern Mississippi embayment: Technical report to U.S. Geological Survey, Reston, Virginia, under Contract 03HQGR0011 (available at http://erp-web.er.usgs.gov), 19 p.

Cox, R.T., Larsen, Daniel, Forman, S.L., Woods, Jamie, Morat, Jason, and Galluzzi, Joseph, 2004b, Preliminary assessment of sand blows in the southern Mississippi embayment:

Bulletin of the Seismological Society of America, v. 94, no. 3, p. 1125-1142.

Cox, R.T., Larsen, Daniel, and Hill, A.A., 2004c, More paleoliquefaction data from southeastern Arkansas-Implications for seismic hazards: Geological Society of America Abstracts with Programs, v. 36, no. 2, p. 119.

Cox, R.T., Van Arsdale, R.B., Harris, J.B., Forman, S.L., Beard, William, and Galluzzi, Joseph, 2000b, Quaternary faulting in the southern Mississippi embayment and implications for tectonics and seismicity in an intraplate setting: Geological Society of America Bulletin, v. 112 , p. 1724-1735.

Engdahl, E.R., compiler, 1988, Seismicity map of North America: Boulder, Colorado, Geological Society of America Continent-Scale Map 004, 4 sheets, scale 1:5,000,000.

Obermeier, S.F., 1996, Using liquefaction-induced features for paleoseismic analysis, in McCalpin, J.P., ed., Paleoseismology: San Diego, Academic Press, p. 331-396.

Salvador, Amos, 1991, Origin and development of the Gulf of Mexico basin, in Salvador, Amos, ed., The Gulf of Mexico basin: Geological Society of America, The Geology of North America, v. J, p. 389-444.

Thomas, W.A., 1989, The Appalachian-Ouachita orogen beneath the Gulf Coastal Plain between the outcrops in the Appalachian and Ouachita Mountains, in Hatcher, R.D., Thomas, W.A., and Viele, G.W., eds., The Appalachian-Ouachita Orogen in the United States: Geological Society of America, The Geology of North America, v. F-2, p. 537-553.

Thomas, W.A., 1991, The Appalachian-Ouachita rifted margin of southeastern North America: Geological Society of America Bulletin, v. 103, p. 415-431.

Tuttle, M.P., Schweig, E.S., Sims, J.D., Lafferty, R.H., Wolf, L.W., and Haynes, M.L., 2002, The earthquake potential of the New Madrid seismic zone: Bulletin of the Seismological Society of America, v. 92, p. 2080-2089.

\section{Stafford Fault System, Virginia}

\section{(Class C)}

\section{Reason for Class C assignment:}

The Stafford fault system strikes approximately N.35 E. for a distance of $72 \mathrm{~km}$ along the west bank of the Potomac River in northeastern Virginia (Mixon and Newell, 1976; 1977; Seiders and Mixon, 1981; Mayer and Wentworth, 1983; Virginia Division of Mineral Resources, 1993; Mixon and others, 2000). The system consists of five individual reverse faults that dip steeply northwest and follow the inner margin of the Coastal Plain province (Mixon and others, 2000). Four of the northeast-striking faults form a left-stepping array that, therefore, trends north. From north to south, these four faults are the Dumfries fault zone, Fall Hill fault, Hazel Run fault, and an unnamed fault. The fifth fault of the Stafford fault system, the Brooke fault zone, is northeast of the unnamed fault and on trend with it. The northeastmost strand of the Brooke fault zone is named the Tank Creek fault. 
Two other similar fault zones are southeast of the Stafford fault system and roughly parallel to it. The Skinkers Neck-Brandywine fault zone is 10-20 km southeast of the Stafford fault system, and the Port Royal fault zone is an additional 7-14 km to the southeast (Mixon and Newell, 1977; Mixon and Powars, 1984; Mixon and others, 1992; 2000). However, unlike the Stafford fault system with its uniform southeast-side-down sense of faulting, each of the Skinkers NeckBrandywine and Port Royal fault zones consists of a fault-bounded central block that moved down with respect to both bounding blocks (Mixon and others, 2000). Both fault zones are less well known than the Stafford fault system, and the map of Mixon and others (2000) shows both boundaries of the Skinkers Neck-Brandywine and Port Royal fault zones as dashed lines ("inferred"). South of the Stafford fault system, Coastal Plain sediments are offset by two other small, northeast-striking faults, the Arcadia and Ladysmith faults (Mixon and others, 2000). Thus, the Stafford fault system is the best-studied part of a more extensive group of faults that cut or are inferred to cut the Coastal Plain strata.

The individual faults of the Stafford system dip steeply to the northwest, as shown by geologic map relations, stratigraphic changes across the faults, structure contours from boreholes and exposures, a trench across the Dumfries fault zone, outcrops of some of the faults, streamgradient analyses, and a seismic-refraction profile (Ackermann and Grim, 1977; Mixon and Newell, 1977; 1978; 1982; Mayer and Wentworth, 1983; Rader and others, 1986). The unconformable contact of the Coastal Plain strata with the underlying metamorphic and igneous rocks of the Piedmont province drops 10-60 m southeastward across each fault of the Stafford system (Mixon and others, 2000). Mixon and Newell (1977) and Mixon and others (1992; 2000) suggested that some of the individual faults of the Stafford system formed by contractional reactivation of extensional border faults of Triassic basins.

Displacements that decrease upward in the Coastal Plain section demonstrate recurrent movement on the Stafford fault system beginning in Early Cretaceous time (Mixon and Newell, 1977; Mixon and others, 2000). However, none of the reports and maps cited here document Quaternary movement on any faults of the Stafford system. The youngest documented movement is on the Fall Hill fault of the Stafford system. The fault offsets the base of a Pliocene-Pleistocene sandy gravel by $14 \mathrm{in} .(36 \mathrm{~cm})$, and nearby Cretaceous strata are faulted against part of the same Pliocene-Pleistocene unit (Mixon and Newell, 1978). Additionally, the geologic maps of Seiders and Mixon (1981) and Mixon and others (1989; 2000) show all faults within or bounding the Coastal Plain strata as dotted lines ("concealed") wherever their traces cross mapped Quaternary deposits, with two exceptions: as noted earlier, the Skinkers NeckBrandywine and Port Royal fault systems are mapped as dashed lines ("inferred") in both Quaternary and older deposits.

The conclusion that Quaternary faulting has not been documented would appear to be contradicted at four places. The maps of Mixon and others $(1989 ; 2000)$ show four short parts of the Hazel Run fault and the Brooke fault zone as solid lines where the faults cross Quaternary deposits. However, as explained next, probably all four solid lines are errors of compilation or drafting.

(1) The Hazel Run fault strikes northeast across the southeast-flowing Rappahannock River at Fredericksburg, Virginia (Mixon and others, 2000). On the southwest side of the river the fault trace is shown as dotted where it crosses three middle and late Pleistocene terraces. In contrast, on the northeast side of the river the trace is shown as a solid line where it crosses a terrace of the lower Pleistocene Charles City Formation for a distance of about $200 \mathrm{~m}$. However, the text accompanying the map does not mention any Quaternary faulting. Table 1 of the text lists the youngest unit offset by the Hazel Run fault as the Paleocene Aquia Formation. Finally, R. B. Mixon (oral commun., 2005) characterized this short piece of solid line as "almost certainly a drafting error". 
(2) Mixon and others (1989) mapped the Coastal Plain deposits and structure in the map area of Mixon and others (2000), as well farther north, south, and east. Mixon and others (1989) showed all faults within or bounding the Coastal Plain as dotted lines ("concealed") wherever the traces cross mapped Quaternary strata, with three exceptions on the Brooke fault zone. The first exception is near the north edge of, but within, the area mapped by Mixon and others (2000). The southeast strand of the Brooke fault zone crosses $4 \mathrm{~km}$ of the Sedgefield Member of the upper Pleistocene Tabb Formation. Mixon and others (1989) showed this part of the fault trace as a solid line, but Mixon and others (2000) showed it as a dotted line. W.L. Newell (written commun., 2005) reported that "the solid lines where faults of the Stafford fault system are shown 'cutting' the Upper Pleistocene terraces on the Map I-2033 are almost certainly editorial oversights during the compilation and review of the map. If we had observed actual offsets of these terrace deposits, the impact of that evidence ... would have been significant".

(3) The second exception on the Brooke fault zone is at the north border of the map of Mixon and others (2000). Mixon and others (1989) used a solid line to depict a short fault strand that crosses $1 \mathrm{~km}$ of the combined Lynnhaven and Poquoson Members of the upper Pleistocene Tabb Formation. Mixon and others (2000) do not show this short fault strand. Additionally, the written communication from W. L. Newell, cited in the preceding paragraph, was intended to apply here as well.

(4) Two kilometers farther northeast, the same short fault strand crosses $1.5 \mathrm{~km}$ of the Sedgefield Member. Mixon and others (1989) showed the crossing as a solid line. The Quantico quadrangle map of Mixon and others (1972) shows no faults, but only steep, southeast-facing gradients that are defined by structure contours on the bases of the Paleocene Aquia Formation and the Lower Cretaceous Potomac Group. The Quantico map was published four years before the announcement of the Stafford fault system by Mixon and Newell (1976), so it may not bear on the age of the short fault strand. However, the previously cited, written communication from W. L. Newell was intended to apply here as well.

Thus, none of the strands of the Stafford fault system are known to have moved during the Quaternary. Accordingly, the Stafford fault system is assigned to Class C for lack of demonstrated Quaternary faulting.

State(s):

Virginia

County(s):

Stafford

Prince William

Spotsylvania

Physiographic province(s):

Coastal Plain province; Piedmont province

Compiled or modified by and affiliation:

Russell L. Wheeler, U.S. Geological Survey, 2005

References:

Ackermann, H.D., and Grim, M.S., 1977, Seismic refraction survey of the pre-Cretaceous basement surface near the inner edge of the Coastal Plain in Stafford and King George Counties, Virginia: U.S. Geological Survey Open-File Report 77-480, 14 p.

Mayer, Larry, and Wentworth, C.M., 1983, Geomorphic differences east and west of the Stafford fault system, northeastern Virginia: Geological Society of America Abstracts with Programs, v. 15 , no. 2, p. 56.

Mixon, R.B., Berquist, C.R., Jr., Newell, W.L., and Johnson, G.H., 1989, Geologic map and generalized cross sections of the Coastal Plain and adjacent parts of the Piedmont, Virginia: 
U.S. Geological Survey Miscellaneous Investigations Map I-2033, 2 sheets, scale $1: 250,000$.

Mixon, R.B., and Newell, W.L., 1976, Faults and flexures along the inner edge of the Atlantic Coastal Plain in northeastern Virginia: Geological Society of America Abstracts with Programs, v. 8, no. 2, p. 231-232.

Mixon, R.B., and Newell, W.L., 1977, Stafford fault system-Structures documenting Cretaceous and Tertiary deformation along the Fall Line in northeastern Virginia: Geology, v. 5, p. 437-440.

Mixon, R.B., and Newell, W.L., 1978, The faulted Coastal Plain margin at Fredericksburg, Virginia: Tenth annual Virginia Geology Field Conference, October 13-14, 50 p.

Mixon, R.B., and Newell, W.L., 1982, Mesozoic and Cenozoic compressional faulting along the Atlantic Coastal Plain margin, Virginia, in Lyttle, P.T., ed., Central Appalachian Geology-NE-SE GSA '82 Field Trip Guidebooks: Falls Church, Virginia, American Geological Institute, p. 29-54.

Mixon, R.B., Pavlides, Louis, Powars, D.S., Froelich, A.J., Weems, R.E., Schindler, J.S., Newell, W.L., Edwards, L.E., and Ward, L.W., 2000, Geologic map of the Fredericksburg 30' × 60' quadrangle, Virginia and Maryland: U.S. Geological Survey Miscellaneous Geologic Investigations I-2607, 34 p. pamphlet, 2 sheets, scale 1:100,000.

Mixon, R.B., and Powars, D.S., 1984, Folds and faults in the inner Coastal Plain of Virginia and Maryland-Their effect on distribution and thickness of Tertiary rock units and local geomorphic history, in Frederiksen, N.O., and Krafft, K., eds., Cretaceous and Tertiary stratigraphy, paleontology, and structure, southwestern Maryland and northwestern Virginia: American Association of Stratigraphic Palynologists, Field Trip Volume and Guidebook, p. 112-122.

Mixon, R.B., Powars, D.S., and Daniels, D.L., 1992, Nature and timing of Upper Mesozoic and Cenozoic deposits in the inner Atlantic Coastal Plain-Proceedings of the 1988 U.S. Geological Survey Workshop on the Geology and Geohydrology of the Atlantic Coastal Plain: U.S. Geological Survey Circular 1059, 65-73 p.

Mixon, R.B., Southwick, D.L., and Reed, J.C., Jr., 1972, Geologic map of the Quantico quadrangle, Prince William and Stafford Counties, Virginia: U.S. Geological Survey Map GQ-1044, 1 sheet, scale 1:24,000.

Rader, E.K., Newell, W.L., and Mixon, R.B., 1986, Mesozoic and Cenozoic compressional faulting along the Coastal Plain margin, Fredericksburg, Virginia, in Neathery, T.L., ed., Centennial Field Guide Volume 6-Southeastern Section of the Geological Society of America: Boulder, Colorado, Geological Society of America, p. 309-314.

Seiders, V.M., and Mixon, R.B., 1981, Geologic map of the Occoquan quadrangle and part of the Fort Belvoir quadrangle, Prince William and Fairfax Counties, Virginia: U.S. Geological Survey Miscellaneous Investigations Map I-1175, 1 sheet, scale 1:24,000.

Virginia Division of Mineral Resources, 1993, Geologic map of Virginia: Virginia Division of Mineral Resources, 1 sheet, scale 1:500,000.

\section{Acknowledgments}

A draft of each assessment was sent to one or more geologists or geophysicists who have studied the feature. The assessments benefited from suggestions by S.J. Baxter, R.T. Cox, R.D. Hatcher, Jr., L.T. Long, R.T. Marple, P.C. McLaughlin, R.B. Mixon, W.L. Newell, Pradeep Talwani, W.G. Thompson, and R.W. Weems. Suggestions of A.J. Crone and K.M. Haller improved the entire report. Additionally, information copies of the assessments were sent to the pertinent State Geologists. 